\title{
Against the Grain? Assessing Graduate Labour Market Trends in Germany Through a Task-Based Indicator of Graduate Jobs
}

\author{
Golo Henseke ${ }^{1}$ (D)
}

Accepted: 20 January 2018 / Published online: 30 January 2018

(C) The Author(s) 2018. This article is an open access publication

\begin{abstract}
Applying work by Green and Henseke (in IZA J Labor Policy 5(1):14, 2016a), this study examines changes in the German graduate labour market in the twenty-first century. To do so, it deploys a new statistically derived indicator of graduate jobs, based on job skill requirements obtained from worker-reported task data in the German Employment Surveys 2006 and 2012. As in previous work, the resulting classifier explains differences in graduate labour market outcomes better than existing methods and can be applied in a range of contexts where intelligence on graduate destinations is desired. It is supplied in the appendix of this study. Despite the expansion of higher educational attainment between 1999 and 2012, my analysis indicates a rising excess demand for graduate labour. Following key findings emerge:
\end{abstract}

- Graduate skills are required beyond the narrow range of professions. Work tasks associated with cognitive skills use are key determinants of higher education requirements on the job.

- The proportion of graduates in the age bracket 25-34 has risen among men from 14.7 to 18.9\% and from 13.3 to $22.5 \%$ among women between 1999 and 2012. Young women have become the group with greatest level of higher education in the labour market.

- The growing supply of graduate labour in the age bracket 25-34 was surpassed by the expansion of employment in graduate jobs. The employment share of graduate jobs shifted by 17 percentage points to almost $30 \%$ among young women and by 11 percentage points to $28 \%$ among young men.

- Among young female graduates, the incidence of underemployment fell to $22 \%$ between 1999 and 2012; roughly comparable to the level among males at the same ages. Prime aged female graduates, however, experience above average rates of underemployment.

Golo Henseke

g.henseke@ucl.ac.uk

1 UCL Institute of Education, Centre for Global Higher Education, 20 Bedford Way,

London WC1H 0AL, UK 
- A sharp rise of the pay premium associated with higher education among men contrasts with stagnating wage differentials among women.

- The pay penalty associated with underemployment has not changed statistically significantly.

Keywords Higher education · Graduate jobs · Underemployment · Wages · Wage dispersion

\section{Introduction}

This paper sets out to derive an indicator of graduate jobs grounded in skill use at work. Although the indicator is deployed here to examine the graduate labour market in Germany in the twenty-first century, wider applications in career counselling, employment services or policy advisory are conceivable. Along with our earlier work in Green and Henseke (2016a) and Henseke and Green (2017), the outlined methodology can serve as a blueprint for similar indicators in countries where worker-reported data on education requirements and work tasks are available.

While higher education systems across the world started to expand in the 1980s and 1990s, Germany's attainment levels have remained low and have increasingly fallen behind in international comparison (OECD 2008). Traditionally, high-quality vocational education and training (VET), either through the renowned 'Dual System' or in a fully qualifying school-based system, has provided alternative pathways into skilled employment in contrast to countries with polarized post-secondary education systems. But since 2005, gross enrolment in higher education has surged by roughly 20 percentage points and stands now at above 50\%: more youth choose to continue with higher education than to enter the vocational education sector (Destatis 2016).

Where some scholars have welcomed the increasing participation in higher education, others have posed the question of how the labour market will absorb this 'glut' of new university graduates (e.g., Hirsch-Kreinsen 2013; Nida-Rümelin 2014). Compared with other high-income countries, the German economy deploys relatively little labour in 'graduate jobs', which could limit the range of adequate employment opportunities for new graduates (Henseke and Green 2017). Technological change, globalisation, as well as changing management practices are thought to complement graduate skills and thus drive up demand (e.g., Akerman et al. 2015; van Reenen 2011; Blinder and Krueger 2013; Foster-McGregor et al. 2013; Green 2012), whilst substituting for codifiable and offshorable-'routine'work tasks (Autor et al. 2003, 2008). The hypothesis of 'routinization' provides a strong narrative for why the growing supply of graduate labour in many countries has been met with stable or even increasing pecuniary returns, when the middle of the job skill distribution has been hollowing out (e.g., Goos et al. 2014; Dustmann et al. 2009).

Demand for high-skilled labour is typically inferred indirectly from wage differentials (e.g., Katz and Murphy 1992; Michaels et al. 2014). In the case of Germany, there is good evidence for a substantial and, since the end of the 1990s, steadily growing wage premium associated with higher education for recent graduates (Christoph et al. 2017; Reinhold and Thomsen 2017). In the US, by contrast, relative wages associated with college education have changed little since the early 2000s after years of continued growth (Valletta 2017). In Britain, average relative wages of university graduates remained stable over the period 
of massification in the early 1990s and its aftermath but have begun to slowly decline for more recent cohorts (e.g., Walker and Zhu 2008; Blundell et al. 2016). While it is theoretically possible to derive estimates of demand shifts from wage trends, the results do not always align well with observed labour market patterns (e.g., Dustmann et al. 2009; Blundell et al. 2016).

More direct assessments of demand trends have been hindered by a lack of accepted classifications of graduate jobs. Some methods draw on the distribution of educational attainment and are thus prone to tautological conclusions. Others rely on difficult to test assumptions about the organisation of labour markets, or are at best only loosely related to skills requirement. Most approaches ignore changes of education requirements within occupations altogether. Drawing on work task data and reported education requirements in the BiBB/BAuA Employment Surveys 2006 and 2012, this paper is tasked to derive a statistical indicator of graduate jobs in Germany that is rooted in skill use at work and capable of accommodating demand shifts between and within occupations. To do so, I apply a method developed by Green and Henseke (2016a, b) and Henseke and Green (2017). The method has proven to generate a conceptually valid indicator that predicts a range of graduates' labour market outcomes better than existing methods for the UK and further OECD countries. Throughout the paper, I use the term 'graduate job' as it has entered the common parlance to refer to occupations that require higher education. Jobs are here understood as bundles of work tasks that require certain qualifications to be carried out competently.

In an application, I deploy the derived indicator to examine graduate labour market trends in Germany since 1998/99. If the growing supply of graduates is not met by an equally expanding labour demand, graduates will increasingly divert their skills to non-graduate jobs (Albrecht and Vroman 2002; Dolado et al. 2009; Acemoglu and Autor 2011). This will result in a growing proportion of underemployed graduates, a stagnating or potentially declining higher education wage premium and an increasing dispersion of graduate wages. The findings here confirm that between 1999 and 2012, the growing graduate labour supply has been well absorbed by the labour market: employment in graduate jobs grew, the higher education wage premium rose among male graduates, underemployment dropped for young university educated women, whilst the pay gap between matched and mismatched graduates did not change significantly. However, underemployment among prime-aged university educated women remains at above average levels. Moreover, a slowdown in the expansion of graduate jobs after 2006 may indicate rising clouds on the horizon.

The contribution of this paper is thus twofold. Firstly, the paper applies the methodology developed in Green and Henseke (2016a) to derive and validate an indicator of graduate jobs for Germany. Secondly, by deploying the indicator it assesses underemployment patterns as well as changes of the higher education wage premium and the dispersion of earnings within university graduates since the end of the 1990s. In doing so, this paper brings together usually disjoint research strands on underemployment, wage differentials by education, and the demand for graduate skills. It provides empirical, bottom-up evidence on how the labour market fortunes of graduates have changed, and the emergence of new graduate jobs at the margin between the HE and VET sector. It contributes to international discourse about graduate labour market outlooks in times of HE massification and national debates on the 'academisation' of qualification systems and the world of work.

The paper is organised as follows. Section 2 summarises key features of the German post-secondary education system, before Sect. 3 discusses concepts of graduate jobs. The datasets to derive and validate the classifier of graduate jobs on one hand, and to analyse labour market trends on the other are introduced in Sect. 4 . Section 5 describes the 
methodology and derives the classifier of graduate jobs. Section 6 deploys the derived classifier to analyse the state of the graduate labour market and its relationship with individual outcomes, before the final section concludes.

\section{The German Post-secondary Qualification System}

Traditionally, high-quality vocational education and training (VET), either through the renowned 'Dual System' or in a fully qualifying school-based system, has provided an important pathway into skilled employment for most school-leavers in Germany. Even for youth who have obtained the higher education entrance certificate (Abitur), further qualification through the VET sector has often been the preferred choice. Higher-ranking VET programmes that lead into business and public associate professional occupations, such as management assistants, or occupations surrounding information and communication technologies, such as graphic and multimedia designers in fact often make the Abitur a requirement (Powell and Solga 2011). In 2012, around half of all workers aged 25-64 who held an Abitur pursued vocational education either exclusively or in addition to a degree programme at university. The result is a broad post-secondary qualification structure that offers multiple access nodes into good and well-paid employment in contrast to more polarized qualification systems that distinguish mainly between college graduates and high school leavers (Protsch and Solga 2016).

In addition to alternative post-secondary qualification pathways, a segregated school system with widespread early academic tracking has also limited wider access to higher education. Over the last decade, however, numbers of high-school graduates eligible to enter HE has risen. In 2015, despite shrinking birth cohorts, there were 445,400 students who obtained the university entrance diploma up from 399,400 ten years earlier. At the same time, transition rates from school to higher education have soared: in the 2005 school-leaver cohort 58\% were enrolled in higher education 2 years after finishing school, whereas almost three quarters of school-leavers from 2013 moved on to higher education within 2 years after finishing school (Destatis 2016).

More widespread forms of contingent employment, income insecurity and the growing demand for general competences in the labour market may have further contributed to the diminished attractiveness of VET among high-achieving youth (Jacob and Solga 2015). Despite advantages at career start (Wolter and Ryan 2011; Klein 2015), vocational skills are at greater risk to become obsolete as technology progresses (Lamo et al. 2011; Hanushek et al. 2017). Moreover, a growing HE sector with a wider offering of courses such as short degree programmes (bachelor's degree), sandwich courses that sometimes combine a higher education degree with a vocational qualification, or programmes for parttime students and long-distance learners have contributed to a greater pull of HE (Autorengruppe Bildungsberichterstattung 2014; Wolter and Kerst 2015). These growing vocational components in the HE system together with rising participation have created tensions at the margin between the historically segregated VET and HE sectors (e.g., Autorengruppe Bildungsberichterstattung 2016; Baethge and Wolter 2015). Thus, occupations at the margin between both sectors may increasingly draw on graduate skills and less on expertise taught during vocational training. 


\section{Concept of a Graduate Job}

The concept of graduate jobs is central to this article. Following Green and Henseke (2016a), we think of a graduate job to be one where “... a substantial portion of the skills used are normally acquired in the course of higher education, including many of the activities surrounding it, and of its aftermath-the years after higher education when skills are acquired in work through graduates' acquired faculty for learning them" (Green and Henseke 2016a: p. 3). Building on a body of skills and knowledge acquired in and outside of formal schooling, higher education is thought to endow students with professional expertise and to strengthen a range of generic skills such as problem-solving, decisionmaking, teamwork, research skills, or capacity to learn (Allen and Van der Velden 2011; Teijeiro et al. 2013). Students will gain competences during formal education, informal learning activities such as work placements or volunteering, during other forms of extracurricular activities and through peers. By contrast, although generic competences such as professional communication, team work or planning work processes are typically part of the curriculum of TVET programmes in Germany, firm- and industry-specific components will necessarily receive greater attention particularly in the dual system (Hanushek et al. 2017; Weber 2014).

By enabling graduates to utilise their skills, graduate jobs provide the pathway through which higher education becomes productive in the economy. For the individual, holding a graduate job implies reaping the labour market benefits from higher education through, for example, better income, greater job satisfaction, and more opportunities for training and career development (Teichler 2009). Though the conceptualisation draws on skills use at work, this does not limit higher education's contribution for individuals and society to paid work (McMahon 2009). As such the concept is neither free from ambiguity nor does it imply that graduates can necessarily make use of all their skills acquired during higher education or that graduates will necessarily be the exclusive suppliers of the required skills especially in occupation at the margin between the graduate and non-graduate sector.

National institutional configurations and labour market circumstances will shape the mapping of graduate skills to work tasks. Organisations decide on the deployment of new technologies, on how to structure work processes or what task to outsource, and thus how to design jobs. Dominant management practices, institutional characteristics of labour and product markets, and the availability and relative quality of other sources of high skilled labour will impact organisations' decision on which qualification group to allocate to which task (Acemoglu and Autor 2011; Dustmann and Glitz 2015). Though high-skill jobs will typically require tertiary educated labour to be carried out competently, other post-secondary qualification may provide the required skills depending on the selectivity and quality of countries' education system. According to data from the OECD's Survey of Adult Skills, in Germany $45 \%$ of adults with high levels of numeracy skills (>326 points on the numeracy scale) hold non-HE post-secondary qualifications compared with $23 \%$ in the UK or $20 \%$ in the US. A valid classification of graduate jobs should account for these country differences.

Furthermore, mapping of graduate skills to work tasks changes dynamically as occupation "upskill" through, for example, enrichment with non-routine tasks. ICT-related occupations, associate professional occupations in social care and pre-primary teaching, new occupations that draw heavily on interpersonal skills, or technicians that require high-levels of professional and scientific expertise may be examples of jobs that have professionalised to a point where graduates can make effective use of their skills and knowledge (Alesi and Teichler 2013; Schütte 2013). As skill-biased technology change continues and the fraction 
of professional and vocational components in HE curricular expands, a wider range of jobs may begin to require skills that are typically acquired during higher education (Drexel 2010).

\section{Data and Classification}

\subsection{Existing Classifications of Graduate Jobs}

The traditional notion of professions or high-level management as graduate jobs has lingered on in scholarly examinations and public discourse of graduate labour market destinations. This perception is often based on a normative understanding of graduate jobs defined by legal licensing regulations that restrict access to professions to certain higher education credentials. By drawing on skills use at work, the here proposed approach can accommodate a wider range of occupations that utilise skills acquired through higher education.

Different methods in the international research literature have attempted to delineate graduate employment. The most common is based on the distribution of higher education graduates across occupations (e.g., Verdugo and Verdugo 1989; Kiker et al. 1997; Boll et al. 2016; Mateos-Romero and del Mar Salinas-Jiménez 2017; Summerfield and Theodossiou 2017). Though it can be delivered in a subtle way (Elias and Purcell 2004), this supply-driven approach has received criticism due its tautological deduction of educational requirements from distributions of educational attainment. Another proposition defines graduate jobs based on occupation-specific higher education pay premiums (Gottschalk and Hansen 2003; O'Leary and Sloane 2016). While having theoretical appeal, the approach relies on restrictive assumptions about the organisation of labour markets that may not hold in practice. Closest to the here applied concept of graduate job are classifications that draw on expert knowledge to cluster occupations based on typical work tasks (Elias and Purcell 2013 for the UK; Cattani et al. 2014 for Italy). However, such expert-based systems are somewhat lacking in transparency, are difficult to replicate and can generally only be updated at great expenses.

Albeit less detailed, occupational classifications typically integrate expert-derived skill levels as a structuring element. Occupational skill levels in, for example, the British Standard Occupational Classification (SOC) or the International Standard Classification of Occupations (ISCO) link levels of job complexity to educational requirements and thus provide an approximation of graduate jobs. With the introduction of skill levels in the revised German standard occupational classification — "Klassifikation der Berufe 2010" (KldB-10) - this has become an option in data coded to the German classification framework, too. Like ISCO, KldB-10 distinguishes between four skill levels. The highest skill level describes highly complex occupations that require at least four years of higher education (Paulus and Matthes 2013). However, so far there has been no independent evaluation of Kldb-10's skill levels. Moreover, there is currently no accepted approach to identify graduate jobs in data coded to the German occupational classification prior to the introduction of KldB-10 in 2011. Consequently, demand for graduates cannot easily be traced over longer periods.

I apply methods developed in Green and Henseke (2016a) and Henseke and Green (2017) to German work-task data to close these gaps. In previous work, the classification method has been shown to produce plausible distribution of graduate jobs and is generally 
able to explain differences in labour market outcomes among graduates better than hitherto existing approaches across a wide range of different labour market configurations.

\subsection{Data}

I use a combination of datasets to, first, derive the graduate classifier and then to examine graduate labour market trends.

Primary data source are the last three waves of the BiBB/BAuA Employment Surveys (1998/1999, 2005/2006 and 2011/2012). These representative cross-sectional surveys include information on job content, individual socio-demographic characteristics, qualification histories and the worker-job fit. The here applied classification requires workerreported education requirements, which is available in waves 2006 and 2012. Both waves collected data from around 20,000 fully employed people, i.e., people who were at last 15 years old at the time of sampling and who worked for at least $10 \mathrm{~h}$ per week. Where feasible, I also draw on earlier data from 1999 to examine changes in the graduate labour market. While all three surveys share the same target population, the interview mode has switched from face-to-face to telephone between 1999 and 2006. To correct for differential non-response, I use the supplied survey weights throughout the analysis. These weights adjust for non-response along multiple dimensions including occupational position.

For further external validation, I draw on data from the adult start cohort of the National Educational Panel Study (NEPS). NEPS is an annual longitudinal study of adults, their education and employment trajectories as well learning activities and skills acquisition after leaving school since. Data collection commenced in 2007/08.

Finally, to analyse graduate labor market trends, I also use information from the German sample of the EU Labour Force Survey (EU-LFS). The EU-LFS is a quarterly rotating sample survey of the population in private households in currently 33 European countries. For the analysis, I use the annual German LFS files.

See the data appendix for more technical detail on these data collections.

\subsection{Occupation Codes and Variables}

In the following, I group KldB-10 occupations as well as 3-digit KldB-92 occupations into graduate and non-graduate jobs. KldB-92 was a national framework to structure occupational information in surveys and some administrative data before it was superseded by KldB-10 in 2011. Six broad occupational fields formed the top level of the hierarchy that differentiated into more nuanced units with each step down the occupational hierarchy. 396 3-digit occupations formed the standard units for statistical purposes. Unlike KldB-10, it did not structure occupations by skill level.

To classify Kldb-10 coded occupations, occupational main-groups (2-digit) are combined with the skill level descriptors at the 5th digit of the occupational nomenclature. For more frequent main-groups in services (sales occupations in retail, business management and organization, financial services, accounting and tax consultancy, medical and health care, education and social work, and in teaching and training), the level of detail is increased to the 3 rd digit.

To minimize the influence of sampling error on the classification, occupations with less than ten observations in either 2006 or 2012 were aggregated into larger units following aggregation rules suggested in Tiemann et al. (2008). Table 9 in the appendix summarises the applied recoding rules. 
The classifier draws on worker-assessed education requirements, work task data and additional information on generic skill requirements of work.

Self-assessed educational requirements of the current job are inquired by "What type of professional qualification is typically required to do your job?". Response options are university qualification, professional tertiary education, vocational training, or neither. Responses are dichotomised to distinguish jobs that require higher education (1) from those that do not (0).

Though workers are generally well placed to assess the qualification required to do their jobs, survey responses may be confounded by measurement error (Verhaest and Omey 2006, 2012). Workers may frame their responses around qualification levels required to get the job, typical qualification of workers in similar jobs, or their individual educational attainment. It also conceivable that social desirability introduces an upward bias into individuals' subjective assessments. Moreover factors pertaining to job satisfaction or wages could have a reverse effect on workers' assessment of education requirements. I thus supplement this information with data on determinants of high-skills use at work. The allocation of task items follows loosely Spitz-Oener's (2006) approach to describe interpersonal and cognitive intensive work tasks. Particularly the latter task group describes main activities across occupations that require higher education (Dengler et al. 2014). The items entail:

1. Cognitive intensive tasks: research, development and design; information collection and documentation; solving new or unfamiliar problems; low level of task repetition; low level of externally prescribed work tasks; planning own work schedule.

2. Interpersonal tasks: consulting and advising; negotiating (convincing others and developing compromises); management and supervision.

3. Expertise: Level of mathematical skills; level of German skills; level of foreign language skills; level of project management skills; level of computer use.

In addition to micro-level information, the classifier will also deploy occupation averages of these items.

To capture further systematic occupation differences between occupations, I also define a measure of self-reported higher education requirements in similar jobs. By construction jobs within the same occupation (KldB-92 or KldB-10 based) share similar work tasks and duties. For each worker, there is thus a neighbourhood of alike jobs within occupations and survey year. Formally,

$$
\widetilde{H E}_{i}=\frac{1}{K(i)} \sum_{k=1}^{K} H E_{k(i)}
$$

where $K(i)$ counts the number of observations by occupation and year and $H E_{k(i)}$ indicates whether job $k$ in the neighbourhood of respondent's $i$ is reported to require a higher education degree.

This list of variables is neither exclusive nor does it imply that a graduate job is characterised by all these attributes nor that any specific task could not be carried out by nongraduates. It is rather an attempt to measure job-domains that in combination contribute to higher education requirements. 


\subsection{The Classifier}

The methodology applies the procedure outlined in (Green and Henseke 2016a; Henseke et al. 2017). The aim is to maintain the variation in worker-assessed higher education requirements that is associated with the observed job and occupation characteristics and in doing so condition out measurement error.

First, I aggregate work tasks and job skills into an index of higher education requirements. In the second step this index is aggregated by occupations, before, in step 3, occupations are clustered into a group of graduate and non-graduate jobs.

Step 1 derives a job-specific score of higher education requirements from a probit regression of worker-reported higher education requirements on the outlined work task items. The dependent variable is thought of as an indicator of latent higher education requirements. The model retains the variation in worker-reported higher education requirements that can be attributed to the explanatory variables. Estimations are run separately for each survey wave and occupational classification. Table 10 in the appendix reports the estimated probit coefficients. From these estimates, I predict a job-specific value of higher education requirements as the linear combination of the covariates weighted by their probit coefficients.

Step two computes occupation-level averages of the predicted job-level higher education requirements by data wave. The recode of occupational codes ensures that there are at least ten observations per occupation-wave cell.

The final step deploys k-medians clustering to split occupations into two distinct, nonoverlapping groups of graduate and non-graduate jobs based on the computed higher education requirement index. K-medians assigns observations to the nearest clusters to minimise the distance between observation and the closest cluster centre (Everitt and Dunn 2001). Jobs above the derived cut-point are deemed to make good use of skills and knowledge typically acquired during higher education.

The marked differences in the construction and organising principles between KldB92 and KldB-10 reflect in different thresholds. For KldB-10, the cut-point between graduate and non-graduate jobs is -0.421 (equal to a predicted probability of worker-reported higher education requirements of 0.37 ), while the cut-point for KldB-92 is -0.607 (corresponding to a predicted probability of 0.27 ). The different thresholds are mostly due to a sharper distinction between the graduate and non-graduate cluster in KldB-10. Figure 1 compares the distribution of the derived occupation-specific higher education requirements index within KldB-10's skill level categories. Most 'highly complex' occupations are classified as graduate jobs. However, there is considerable variation in higher education requirements within occupation skill levels and several complex jobs also appear to require graduate skills.

The resulting classifications are termed $\mathrm{KldB}(\mathrm{HE}) 92$ and $\mathrm{KldB}(\mathrm{HE}) 10$, respectively. Tables 11 and 12 in the appendix list graduate jobs, separately by survey year and occupational classification. For most occupations, the classifier is decisive but there is ambiguity at the margin between graduate and non-graduate jobs. I test whether an occupation's higher education requirement index is significantly different from the computed threshold. Cases which do not reject the null hypothesis at the 5\% level are highlighted in italics.

$\mathrm{KldB}(\mathrm{HE}) 92$ is derived separately for 2006 and 2012 and can thus accommodate changing higher education requirements within occupations. For the clear majority of 3-digit occupation, $\mathrm{KldB}(\mathrm{HE}) 92$ is time-invariant, but there are a few cases which may have changed cluster between the survey waves (Table 11). Upon closer inspection, however, all these cases were situated or have moved into the italics area for which group assignment is 


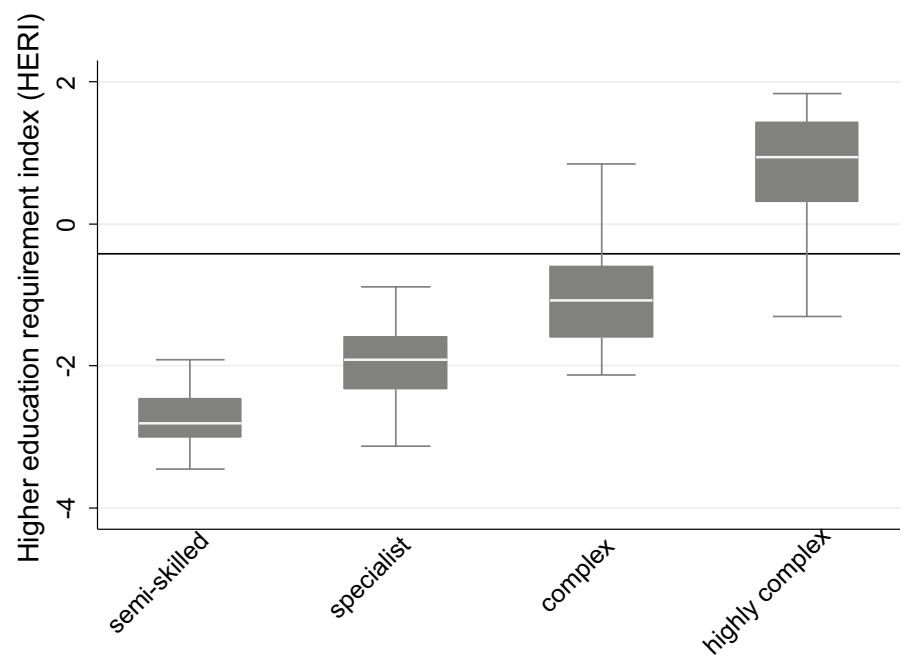

Fig. 1 Higher education requirements by Kldb-10 skill levels. Notes: Box plot of higher education requirement index by KldB-10 skill level. A box's edges are determined by the 25 th and 75 quartile, respectively. The line within boxes represents the median. The whiskers cover all values within 1.5 times the Interquartile Range above the 75 th and below the 25 quartiles. Outliers are suppressed

ambiguous. Thus, I also derive a time invariant $\mathrm{KldB}(\mathrm{HE}) 92$ index following the outlined procedure. The classification is again listed in Table 11 in the appendix to this paper.

Access to some professions such as physicians, engineers, architects or dentists is legally regulated (Haupt 2016). In these cases, standardised professional education credentials are typically essential for access and practice. The classifiers identify those occupations as graduate-level jobs.

To establish criterion validity, the next step scrutinises the performance of $\mathrm{KldB}(\mathrm{HE}) 92$ and $\mathrm{KldB}(\mathrm{HE}) 10$ in explaining differences in graduate labour market outcomes against alternative classifiers. Graduates in graduate jobs ought to be able to make better use of their skills, have greater earnings, enjoy higher levels of jobs satisfaction and have better opportunities for career progressions, through for example, participation in workplace training (e.g., Boccuzzo and Gianecchini 2015; Teichler 2009). KldB(HE)92 and $\mathrm{KldB}(\mathrm{HE}) 10$ are compared against an indicator of 'highly complex' KldB-10 occupations and an index that groups KldB-92 3-digit occupations according to the modal level of education. This latter indicator, which is based on realised matches, acts as a benchmark for the here derived $\mathrm{KldB}(\mathrm{HE}) 92$ classifier.

Table 1 summarises the four classifiers that will be compared in the following. To validate, I draw on data from BiBB/BAuA Employment Survey 2012. Table 2 summarises the estimation results.

As hypothesised, graduates in graduate jobs can make better use of their skills (I), have greater earnings (II), enjoy higher levels of job satisfaction (III), and participate more often in workplace training (IV) than their mismatched counterparts. $\mathrm{KldB}(\mathrm{HE}) 10$ improves over $\mathrm{KldB}(\mathrm{SL} 4) 10$. Across outcomes, $\mathrm{KldB}(\mathrm{HE}) 10$ achieves the most precise estimates: Its Akaike Information Criterion (AIC) is typically 10 or more points smaller and thus represents a substantial improvement over KldB(SL4)10 (Burnham and Anderson 2004). $\mathrm{KldB}(\mathrm{HE}) 92$ does better than $\mathrm{KldB}(\mathrm{SL} 4) 10$ for some outcomes and is a clear improvement 
Table 1 Overview over graduate job classifiers

(1) $\mathrm{KldB}(\mathrm{HE}) 10$ [new] Statistically derived classifier of KldB-10 occupations (generally, first two digit + skill level descriptor). KldB-10 was introduced in 2011. Based on worker-reported education requirements, work task data and further jobcharacteristics. Occupations with higher education requirements above a statistically derived threshold are classified as graduate jobs

(2) $\mathrm{KldB}(\mathrm{SL} 4) 10$ [new]

Expert-based classifier of occupational skill levels at the 5-digit level of KldB10. KldB-10 was introduced in 2011. Skill level four (SL4) indicates occupations that require higher education to be performed well

(3) $\mathrm{KldB}(\mathrm{HE}) 92$ [legacy] Statistically derived classifier of 3-digit KldB-92 occupations. KldB-92 was a commonly applied occupational classification in past labour market data. Based on worker-reported education requirements, work task data and further job-characteristics. Occupations with higher education requirements above a statistically derived threshold are classified as graduate jobs

(4) KldB(RM)92 [legacy] Statistical classifier of 3-digit KldB-92 occupations based on realized matches. KldB-92 was a commonly applied occupational classification in past labour market data. Following the approach by Kiker et al. (1997), graduate jobs are jobs where the modal workers has graduated from university

over $\mathrm{KldB}(\mathrm{RM}) 92$. If $\mathrm{KldB}(\mathrm{SL} 4) 10$ is an indicator of graduate jobs, $\mathrm{KldB}(\mathrm{HE}) 92$ can be considered a valid tool to analyse past graduate labour market trends, whereas $\mathrm{KldB}(\mathrm{HE}) 10$ provides a sharper picture than hitherto possible. $\mathrm{KldB}(\mathrm{RM}) 92$, by comparison, comes in last. Further external validation using data on earnings and training participation in NEPS confirms the conclusions (see Table 13 in the appendix).

As in previous work, the classifier generates a plausible distribution of graduate jobs and predicts graduate labour market outcomes better than hitherto existing methods. Given repeated job and labour market data across years, it can thus be used to examine within and between occupation changes in the prevalence of graduate job.

In the following, the indicator will be deployed to analyse changes in the graduate labour market in Germany in the twenty-first century.

\section{Occupational Upgrading}

Job complexity and educational requirements are likely to evolve, for example, as result of technical change or globalisation. Occupations that draw on interpersonal skills or scientific and technical expertise may increasingly utilise graduate skills as knowledge requirements grow. At the same time, the labour market entry of the first Bachelor cohorts may have created new occupational niches at the margin between HE and VET and thus have pushed the boundaries of what can be considered a graduate occupation outward.

In what occupations have higher education requirements risen? Table 3 displays the ten KldB-92 occupation for which the derived higher education requirement index (HERI) grew strongest between 2006 and 2012. HERI is z-standardized for easier comparison. On this scale, the threshold between graduate and non-graduate occupations is 0.5 , i.e., half a standard deviation above the mean.

Among the occupations on this list, HERI rose by more than half a standard deviation. Technicians, farm/forestry managers and education professionals such as teachers for special needs are among the occupation that upgraded. Skilled trades such as carpenters, potters and glass-makers also appear among the top ten, but predicted higher education 
Table 2 Graduate labour market outcomes by occupational category, 2012. Source: BiBB Employment Survey 2012. Employed graduates in the age bracket 25-64 years

\begin{tabular}{|c|c|c|c|c|}
\hline & $\begin{array}{l}(1) \\
\text { KldB(HE) } 10 \\
\text { [new] }\end{array}$ & $\begin{array}{l}(2) \\
\text { KldB(SL4)10 } \\
\text { [new] }\end{array}$ & $\begin{array}{l}(3) \\
\text { KldB(HE)92 } \\
\text { [legacy] }\end{array}$ & $\begin{array}{l}(4) \\
\text { KldB(RM)92 } \\
\text { [legacy] }\end{array}$ \\
\hline \multicolumn{5}{|c|}{ (I) Worker-reported skills match (probit, AME) } \\
\hline Graduate job & $\begin{array}{l}0.0894 * * * \\
(0.012)\end{array}$ & $\begin{array}{l}0.0726 * * * \\
(0.010)\end{array}$ & $\begin{array}{l}0.0981 * * * \\
(0.012)\end{array}$ & $\begin{array}{l}0.0746^{* * * *} \\
(0.010)\end{array}$ \\
\hline $\mathrm{N}$ & 4280 & 4280 & 4280 & 4280 \\
\hline $\mathrm{AIC}$ & 2849.9 & 2863.4 & 2838.1 & 2861.9 \\
\hline \multicolumn{5}{|c|}{ (II) Hourly earnings (OLS) } \\
\hline Graduate job & $\begin{array}{l}0.262 * * * \\
(0.018)\end{array}$ & $\begin{array}{l}0.238 * * * \\
(0.016)\end{array}$ & $\begin{array}{l}0.239 * * * \\
(0.018)\end{array}$ & $\begin{array}{l}0.186 * * * \\
(0.017)\end{array}$ \\
\hline $\mathrm{N}$ & 3396 & 3396 & 3396 & 3396 \\
\hline AIC & 3998.7 & 4008.3 & 4042.2 & 4101.4 \\
\hline $\begin{array}{l}\Delta_{i} \\
\text { (III) Job satisy }\end{array}$ & & \multicolumn{3}{|c|}{ (III) Job satisfaction (OLS) } \\
\hline Graduate job & $\begin{array}{l}0.270 * * * \\
(0.034)\end{array}$ & $\begin{array}{l}0.233 * * * \\
(0.031)\end{array}$ & $\begin{array}{l}0.233 * * * \\
(0.034)\end{array}$ & $\begin{array}{l}0.153 * * * \\
(0.031)\end{array}$ \\
\hline $\mathrm{N}$ & 4275 & 4275 & 4275 & 4275 \\
\hline AIC & $11,572.2$ & $11,582.5$ & $11,591.5$ & $11,617.9$ \\
\hline$\Delta_{i}$ & -10.30 & 0.00 & 9.00 & 35.40 \\
\hline \multicolumn{5}{|c|}{ (IV) Participation in workplace training (Probit, AME) } \\
\hline Graduate job & $\begin{array}{l}0.136^{* * * *} \\
(0.015)\end{array}$ & $\begin{array}{l}0.0953 * * * \\
(0.014)\end{array}$ & $\begin{array}{l}0.117 * * * \\
(0.015)\end{array}$ & $\begin{array}{l}0.0946^{* * * *} \\
(0.014)\end{array}$ \\
\hline $\mathrm{N}$ & 4274 & 4274 & 4274 & 4274 \\
\hline AIC & 4556.9 & 4592.4 & 4579.5 & 4594.4 \\
\hline$\Delta_{i}$ & -35.5 & 0 & -12.9 & 2.0 \\
\hline
\end{tabular}

Dependent variables: (I) skills match (0/1) (II) log hourly earnings (III) job facet satisfaction (z-score), (IV) participation in non-formal trainings. Controls: sex, 5-year age groups, region of work, foreign born dummy. AIC Akaike Information Criteria, $\Delta_{i}=A I C_{i}-A I C_{K I d B(S L 4) 10}$. Robust standard errors in parentheses $* p<0.05 ; * * p<0.01 ; * * * p<0.001$

requirements remain far below the classification cut-point. Among the occupations in Table 3, physical science technicians and construction technician have switched into the graduate cluster, but the index value is in neither case significantly above the cut-point, thus confirming these occupations' position at the margin between HE and VET. Computer associate professionals (not listed in Table 3) also moved from the non-graduate cluster into the group of graduate occupations (HERI rose by 0.25 standard deviations to 0.7 ). By contrast, accounting professionals may have down-skilled; HERI dropped to 0.39 between 2012 and 2006. However, in the case of the former HERI was not statistically significantly below the threshold in 2006, whereas for the latter occupation HERI was not significantly different from the threshold in 2012. In all, despite clearly changing predicted higher education requirements within occupations, this has not resulted in significant switches of occupations between the non-graduate and graduate cluster from 2006 to 2012. 
Table 3 Changing higher education requirements and new graduate jobs

\begin{tabular}{lcccc}
\hline Job title & HERI 2012 & $\Delta_{\text {HERI }}$ & $\begin{array}{l}\text { KldB(HE) } \\
92-2006\end{array}$ & $\begin{array}{c}\text { KldB(HE) } \\
92-2012\end{array}$ \\
\hline $\begin{array}{l}\text { Agricultural engineer, horticultural } \\
\text { technician }\end{array}$ & 1.569 & 0.740 & 1 & 1 \\
Natural science professionals & 2.457 & 0.718 & 1 & 1 \\
Carpenter & -0.591 & 0.706 & 0 & 0 \\
Physical science technicians & 0.501 & 0.663 & 0 & 1 \\
Engineering science technicians & 0.365 & 0.617 & 0 & 0 \\
Farm/forestry managers & 2.166 & 0.591 & 1 & 1 \\
Science professionals & 2.260 & 0.577 & 1 & 1 \\
Construction technician & 0.542 & 0.542 & 0 & 1 \\
Potters, glass-makers & -0.530 & 0.517 & 0 & 0 \\
Education professionals & 2.113 & 0.502 & 1 & 1 \\
\hline
\end{tabular}

KldB-92

Predicted and z-standardized higher education requirement index. Italics indicate statistically insignificant difference between mean predicted higher education requirement index and the classification cut-point

\section{Changing Graduate Labour Market Outcomes}

Leveraging $\mathrm{KldB}(\mathrm{HE}) 92$, I next examine graduate labour market trends in the twenty-first century. Because occupation clusters have remained stable in 2006 and 2012, I draw on the time-invariant version of $\mathrm{KldB}(\mathrm{HE}) 92$ and include data from the 1999 wave of the BiBB Employment Survey where possible. Doing so may understate changes in the demand for graduate skills, but enriches the longitudinal dimension by an additional time point. Analysis is restricted to age groups $25-54$ years as multiple changes in early retirement legislation since the 1990s may confound employment patterns among older workers. As the German labour market continues to exhibit high levels of gender segregation, analyses will be conducted separately for men and women.

\subsection{Employment Trends}

In both the male and female labour force, the fraction of graduates rose significantly between 1999 and 2013. In the male workforce, the proportion increased by 2.4 percentage points to $19.6 \%$, while in the female labour force attainment rose by 4.5 percentage points to $17.8 \%$ (Fig. 2). Growth was faster in the age group 25-34 years, here attainment rose by 4 percentage points for males and more than 9 percentage points for females (Table 4). In the male labour force, despite growing attainment, the proportion of graduates in the age group 25-34 years did not exceed the figures among prime-aged workers; reflecting the stability of education pathways in Germany over the second part of the twentieth century. Young women, by contrast, have become the group with the highest level of higher educational attainment over this period. For comparison, the fraction of graduates in the British labour force rose from 30 to $42 \%$ over a similar time span (Green and Henseke 2016a).

Given the overall modest increase in the proportion of graduates, are there indications that demand has not kept up or is there perhaps evidence that too few graduates have entered the labour market? As shown in column 5 of Table 5, the proportion of graduate 


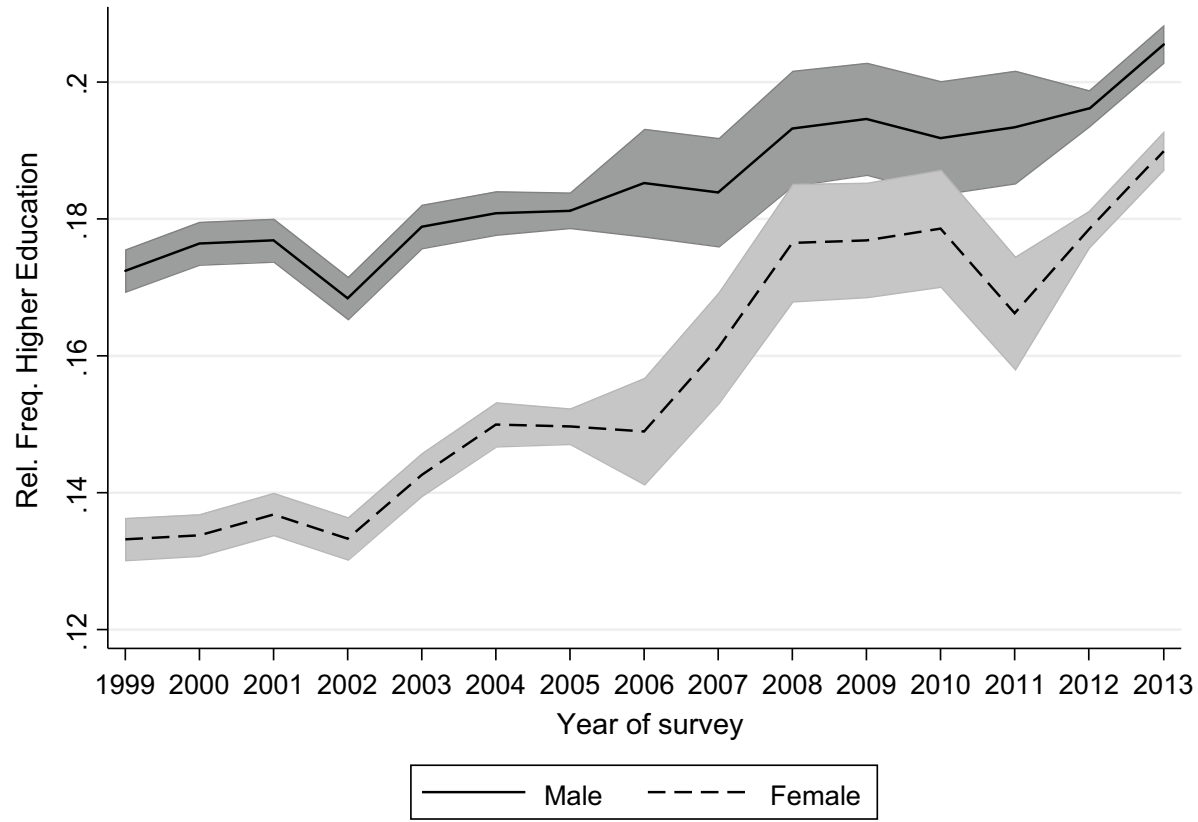

Fig. 2 Proportion of higher education graduates in the labour force, 1999-2013. Population averages for the labour force aged 25-54 years with 95\% CI. Source: EU-LFS, 1999-2013

Table 4 Higher education attainment in the labour force broken down by age and sex, 1999, 2006 and 2012. Source: EU-LFS, 1999, 2005, 2012

\begin{tabular}{lllll}
\hline & 1999 & 2006 & 2012 & $\Delta(2012-1999)$ \\
\hline Male & 0.172 & 0.185 & 0.196 & $0.0237^{* * *}$ \\
& $(0.002)$ & $(0.004)$ & $(0.001)$ & $(0.002)$ \\
$25-34$ & 0.147 & 0.157 & 0.189 & $0.0426^{* * *}$ \\
& $(0.003)$ & $(0.008)$ & $(0.003)$ & $(0.004)$ \\
$35-54$ & 0.185 & 0.195 & 0.199 & $0.0138^{* * *}$ \\
& $(0.002)$ & $(0.005)$ & $(0.002)$ & $(0.003)$ \\
Female & 0.133 & 0.149 & 0.178 & $0.0453^{* * *}$ \\
& $(0.002)$ & $(0.004)$ & $(0.001)$ & $(0.002)$ \\
$25-34$ & 0.133 & 0.186 & 0.225 & $0.0920^{* * *}$ \\
& $(0.003)$ & $(0.009)$ & $(0.003)$ & $(0.004)$ \\
$35-54$ & 0.133 & 0.137 & 0.162 & $0.0285^{* * *}$ \\
& $(0.002)$ & $(0.004)$ & $(0.002)$ & $(0.002)$ \\
\hline \multirow{2}{*}{ 25 } & & &
\end{tabular}

Population averages for the labour force aged 25-54 years. Standard errors in parentheses

$* p<0.05 ; * * p<0.01 ; * * * p<0.001$

jobs has risen from 1999 to 2012 by 4.5 and 8.6 percentage points in the male and female labour force, respectively. Most of the expansion occurred between 1999 and 2006 with only little changes thereafter. 
Table 5 Graduate jobs and graduate underemployment, 1999, 2006 and 2012. Source: BiBB/BAuA Employment Survey 1999, 2006, 2012

\begin{tabular}{|c|c|c|c|c|c|c|c|c|}
\hline & \multicolumn{4}{|c|}{ Employed in graduate jobs } & \multicolumn{4}{|c|}{ Graduates in non-graduate jobs } \\
\hline & 1999 & 2006 & 2012 & $\Delta(2012-1999)$ & 1999 & 2006 & 2012 & $\Delta(2012-1999)$ \\
\hline \multirow[t]{2}{*}{ Men } & 0.220 & 0.267 & 0.265 & $0.0453 * * *$ & 0.236 & 0.243 & 0.250 & 0.0136 \\
\hline & $(0.004)$ & $(0.006)$ & $(0.007)$ & $(0.008)$ & $(0.009)$ & $(0.011)$ & $(0.013)$ & $(0.016)$ \\
\hline \multirow[t]{2}{*}{$25-34$} & 0.171 & 0.241 & 0.282 & $0.111 * * *$ & 0.214 & 0.215 & 0.223 & $0.00,890$ \\
\hline & $(0.006)$ & $(0.010)$ & $(0.014)$ & $(0.015)$ & $(0.018)$ & $(0.023)$ & $(0.028)$ & $(0.034)$ \\
\hline \multirow[t]{2}{*}{$35-54$} & 0.244 & 0.276 & 0.259 & $0.0150^{\#}$ & 0.243 & 0.250 & 0.259 & 0.0163 \\
\hline & $(0.005)$ & $(0.007)$ & $(0.007)$ & $(0.009)$ & $(0.010)$ & $(0.012)$ & $(0.015)$ & $(0.018)$ \\
\hline \multirow[t]{2}{*}{ Women } & 0.144 & 0.207 & 0.230 & $0.0857 * * *$ & 0.308 & 0.323 & 0.308 & 0.000226 \\
\hline & $(0.003)$ & $(0.005)$ & $(0.006)$ & $(0.007)$ & $(0.012)$ & $(0.012)$ & $(0.013)$ & $(0.018)$ \\
\hline \multirow[t]{2}{*}{$25-34$} & 0.129 & 0.224 & 0.296 & $0.167 * * *$ & 0.287 & 0.297 & 0.226 & $-0.0610^{\#}$ \\
\hline & $(0.006)$ & (0.010) & $(0.014)$ & $(0.015)$ & $(0.022)$ & $(0.024)$ & $(0.024)$ & $(0.032)$ \\
\hline \multirow[t]{2}{*}{$35-54$} & 0.152 & 0.200 & 0.205 & $0.0535 * * *$ & 0.316 & 0.332 & 0.349 & 0.0332 \\
\hline & $(0.004)$ & $(0.006)$ & $(0.006)$ & $(0.007)$ & $(0.014)$ & $(0.014)$ & $(0.015)$ & $(0.021)$ \\
\hline
\end{tabular}

Population averages for workers aged 25-54. Standard errors in parentheses

${ }^{\#} p<0.1 ; * p<0.05 ; * * p<0.01 ; * * * p<0.001$

Patterns differ by age. Employment in graduate jobs rose fastest among younger workers; here the share soared by 11 percentage points among males and 17 percentage points among females to 28 and $30 \%$, respectively. By contrast, among prime-aged male workers, initial gains reversed after 2006 and stalled among prime-aged females. Nonetheless, in total, employment in graduate jobs expanded more than the supply of university-educated labour. There may thus have been a growing excess demand for graduates from higher education.

With the increasing demand for graduates and stable assignment of higher education credentials to occupations, underemployment should decline. However, underemployed remained largely stable over the period (Table 5 Column 9). Around a quarter of male and roughly $30 \%$ of female graduates worked in occupations that may make insufficient use of their skills. Only among young female graduates there was a weakly statistically significant drop in the rate of underemployment from 29 to $23 \%$ - a convergence to the figure in the male workforce. The relative high rate of underemployed among prime-aged female graduates is possibly the result of labour market returners after prolonged periods of childrearing.

\subsection{Graduate Occupational Destinations}

Given the non-negligible proportion of underemployed graduates, what are the main occupational destinations? Do most underemployed graduates work in routine occupations in elderly care, as taxi drivers or as baristas as is sometimes suggested (e.g., Dollase 2016) or do underemployed graduates work in occupations that are only slightly below graduate level as Alesi and Teichler (2013) argue?

Table 6 lists the five most frequent 3-digit KldB-10 occupations in 2012 for underemployed graduates by sex. 


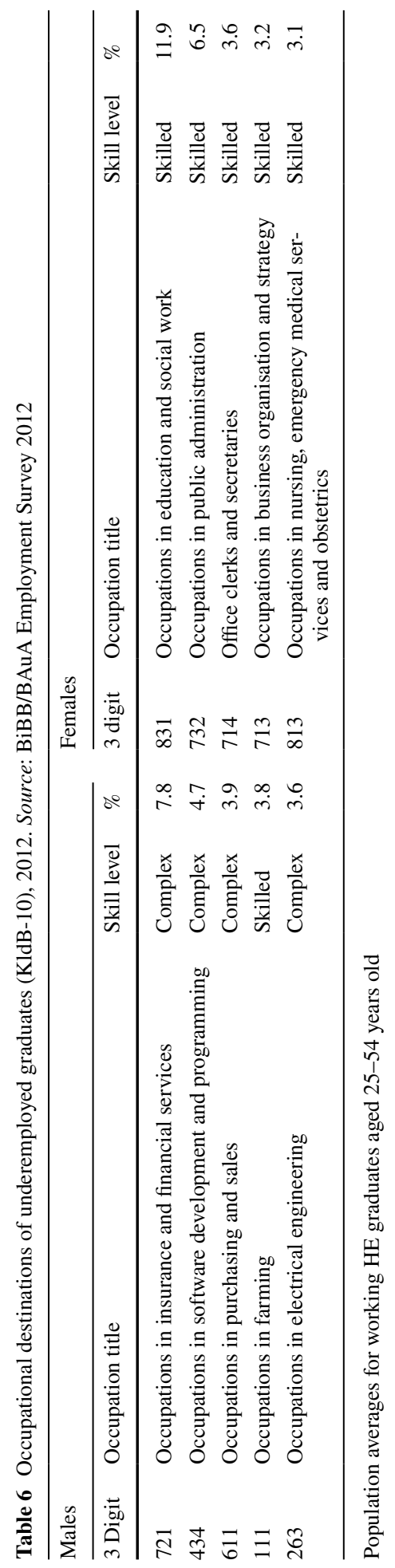


Underemployment male graduates worked frequently in complex associate professional occupations in business related services, commerce and trade, computer services and engineering, but also in farming. Roughly $24 \%$ of underemployed male graduates worked in the listed occupations in 2012. Results in Henseke and Green (2017) suggest that some of these occupations can be considered graduate level jobs, for example, in the Netherlands, Norway or the UK.

By contrast, underemployed female graduates are frequently positioned further down the skill ladder. Most frequent occupations surround activities in teaching, social work and health care as well as in administrative roles in business and the public sector. More than $28 \%$ of underemployed female graduates worked in one of the five occupations listed in Table 6 in 2012.

In all, a gender-segmented picture of underemployment emerges. On one hand, male underemployed graduates frequently work in occupations that are close to graduate roles in terms of job complexity and knowledge requirements. Underemployed female graduates are, on the other hand, deployed more frequently in occupations that formally require upper secondary vocational qualifications. But these occupations are far from low-skill. Within the framework of the International Standard Classification of Occupation 2008, they map partly into sub-major group " 33 Business and Administrative Associate Professionals" and a range of clerical support workers.

To summarise, most underemployed graduates do not appear to work in routine occupations. The 'distance' to a typical graduate job in terms of complexity and skills requirement is, however, gender-specific. This gendered occupation structure is likely to correlate with the pay penalty associated with underemployment.

\subsection{Wage Differentials}

Theory and empirical evidence suggest that changes in graduate employment will correlate with the wage premium from higher education. Especially for young workers, the demand for graduate labour has outstripped the labour supply of graduates. Has the pay premium associated with higher education followed similar patterns?

The following analysis compares wages among workers who have attained the schoolbased university entrance certificate, i.e., are eligible to enrol at an institute of higher education. Many of those will have attained a degree from either a university or a university of applied sciences but a substantive proportion will have completed post-secondary programme without further higher education qualifications. The latter group is going to form the counterfactual against whom I compare graduate earnings. For the analysis, gross monthly wages are converted to log real gross hourly wage rates. Pay information in 1999 is banded over 18 bins ranging from monthly earnings of below $€ 307$ to up to $€ 7669$ or more. These income bands are also converted into log hourly values. To estimate the association of earnings with higher education in 1999, I deploy an interval regression estimator. For the other waves, the higher wage premium is estimated using OLS.

\subsubsection{Higher Education Premium}

Table 7 summarises the estimated graduate log pay premium associated with higher education over time and by demographics. Overall, holding higher education credentials pays off; the earnings advantage of graduates over non-graduates is highly statistically significant, quantitatively substantial, and, at least in the male workforce, on the rise. In the HE 
Table 7 Pay differentials between graduates and nongraduates over time

\begin{tabular}{lllll}
\hline & 1999 & 2006 & 2012 & $\Delta(2012-1999)$ \\
\hline Men & $0.173 * * *$ & $0.224 * * *$ & $0.277 * * *$ & $0.104 * *$ \\
& $(0.020)$ & $(0.023)$ & $(0.032)$ & $(0.037)$ \\
$25-34$ & $0.187 * * *$ & $0.265 * * *$ & $0.312 * * *$ & $0.126 *$ \\
& $(0.030)$ & $(0.034)$ & $(0.050)$ & $(0.059)$ \\
$35-54$ & $0.174 * * *$ & $0.212 * * *$ & $0.256^{* * *} *$ & $0.0818^{\#}$ \\
& $(0.026)$ & $(0.028)$ & $(0.039)$ & $(0.047)$ \\
Women & $0.231 * * *$ & $0.207 * * *$ & $0.205 * * *$ & -0.0253 \\
& $(0.022)$ & $(0.022)$ & $(0.027)$ & $(0.035)$ \\
$25-34$ & $0.211 * * *$ & $0.156 * * *$ & $0.178^{* * *}$ & -0.0329 \\
& $(0.038)$ & $(0.038)$ & $(0.041)$ & $(0.056)$ \\
$35-54$ & $0.249 * * *$ & $0.235 * * *$ & $0.232 * * *$ & -0.0166 \\
& $(0.028)$ & $(0.027)$ & $(0.036)$ & $(0.045)$ \\
\hline \multirow{2}{*}{ 34) } & & &
\end{tabular}

Weighted OLS regression of log hourly pay in 2006 and 2012. Weighted interval regression of log real gross hourly earning bands in 1999. Displayed coefficients are the estimated higher education log wage premium for employees in the age bracket 25-54 who hold a school-based university entrance certificate. Control variables comprise year of birth bands (1945-1949, 1950-1954, 1955-1959, 1960-1964, 1965-1969, 1970-1974, 1975-1979, $\geq 1980$ ), years of potential work experience and its squared value, indicator for the presence of dependent children in the household, a set of state dummies, cohabitation status, foreign nationality and the type of schoolbased university entrance certificate. Number of observation: Men ( $\mathrm{N}=3685 / 2847 / 1966)$, Men 25-34 ( $\mathrm{N}=1231 / 865 / 481)$, Men 35-54 $(\mathrm{N}=2454 / 1982 / 1485)$; Women $(\mathrm{N}=2693 / 2688 / 2135)$, Women 25-34 ( $\mathrm{N}=1013 / 922 / 578)$, Women 35-54 ( $\mathrm{N}=1680 / 1766 / 1557)$. Robust standard errors in parentheses

${ }^{\#} p<0.1 ; * p<0.05 ; * * p<0.01 ; * * * p<0.001$

eligible male workforce, the pay premium grew from initially $18.9 \%(=\exp (0.173))$ in 1999 to $32 \%$ in 2012. By contrast, in the female workforce the wage premium associated with higher education remained stable at around $23-26 \%$. There is no evidence of further differentiation by age. So, while for young female graduates the rate of underemployed dropped, male graduates enjoyed overall a rising pay premium. Though substantial, the estimated pay premium remain below average earnings advantages of college education in polarized qualification system such as the US [average pay premium of more than $75 \%$ in 2010: Valletta (2017)] or the UK [median pay premium of more than $70 \%$ in the period 2006/2012, Green and Henseke (2016b)].

In all, the growing supply of graduates especially among younger workers was not only met but surpassed by the expansion of graduate jobs. In the female workforce, this translated into falling underemployed at a stable wage premium, whereas in the male workforce the underemployment rate remained constant while the pay premium associated with higher education rose significantly. These patterns indicate that the labour market has so far been able to absorb the growing supply of graduates well. But the persistently above average underemployment figures for prime-aged female graduates also indicate that challenging labour market segments remain. 


\subsubsection{The Underemployment Wage Penalty}

Changes of relative average wages associated with higher education will not give a full account of pay dynamics over time. Skill-biased technological change, globalisation and outsourcing are not only conjectured to increase the average pay premium associated with higher education but also contribute to rising dispersion of earnings within graduates (Acemoglu and Autor 2011; Goldschmidt and Schmieder 2017). Rising labour market flexibility through decentralised wage bargaining, declining union power are potential further drivers of growing wage dispersion (Dustmann et al. 2014). Against this backdrop, if the graduate labour supply exceeds demand from graduate occupations, graduates will increasingly compete down the occupational skill ladder to take up non-graduate roles (Green and Zhu 2010). In this case, a growing fraction of graduates may become unable to deploy their skills productivity with negative consequences for their relative earnings. $\mathrm{KldB}(\mathrm{HE}) 92$ offers a lens through which to investigate the evolution of wage differentials between matched and mismatched graduates.

The estimates in Table 8 indicate a stable or even potentially declining wage penalty associated with non-graduate employment. Albeit not statistically significant, the estimated

Table 8 Underemployment pay penalty

\begin{tabular}{lllll}
\hline & 1999 & 2006 & 2012 & $\Delta(2012-1999)$ \\
\hline Men & $-0.167 * * *$ & $-0.213 * * *$ & $-0.0847 *$ & 0.0827 \\
& $(0.029)$ & $(0.036)$ & $(0.042)$ & $(0.051)$ \\
$25-34$ & $-0.116^{*}$ & $-0.212 * * *$ & -0.0544 & 0.0614 \\
& $(0.055)$ & $(0.063)$ & $(0.062)$ & $(0.083)$ \\
$35-54$ & $-0.179 * * *$ & $-0.209 * * *$ & $-0.122 *$ & 0.0576 \\
& $(0.034)$ & $(0.041)$ & $(0.052)$ & $(0.062)$ \\
Women & $-0.253 * * *$ & $-0.198 * * *$ & $-0.183 * * *$ & 0.0695 \\
& $(0.034)$ & $(0.028)$ & $(0.037)$ & $(0.050)$ \\
$25-34$ & $-0.144 *$ & $-0.192 * * *$ & $-0.157 *$ & -0.0132 \\
& $(0.062)$ & $(0.054)$ & $(0.062)$ & $(0.088)$ \\
$35-54$ & $-0.310^{* * *}$ & $-0.203 * * *$ & $-0.211 * * *$ & 0.0994 \\
& $(0.041)$ & $(0.032)$ & $(0.048)$ & $(0.063)$ \\
\hline
\end{tabular}

Weighted OLS regression of log hourly pay in 2006 and 2012. Weighted interval regression of log real gross hourly earning bands in 1999. Displayed coefficients are the estimated wage penalty in log points for underemployed graduates in the age bracket 25-54. Control variables comprise year of birth bands (1945-1949, 1950-1954, 1955-1959, 1960-1964, 1965-1969, 1970-1974, 1975-1979, $\geq 1980$ ), years of potential work experience and its squared value, indicator for the presence of dependent children in the household, a set of state dummies, cohabitation status, foreign nationality and the type of school-based university entrance certificate. Number of observation: Men $(\mathrm{N}=2111 / 1840 / 1286)$, Men 25-34 $(\mathrm{N}=522 / 452 / 269)$, Men 35-54 ( $\mathrm{N}=1589 / 1388 / 1017)$; Women $(\mathrm{N}=1378 / 1605 / 1277)$, Women 25-34 ( $\mathrm{N}=399 / 484 / 315)$, Women 35-54 ( $\mathrm{N}=979 / 1121 / 962)$. Robust standard errors in parentheses

${ }^{\#} p<0.1 ; * p<0.05 ; * * p<0.01 ; * * * p<0.001$ 
wage penalty dropped by roughly $0.08 \mathrm{log}$ points among male and $0.07 \mathrm{log}$ points among female graduates between 1999 and 2012. This can be seen as further indicative evidence that the growing supply of graduates in Germany has so far been well absorbed by the labour market. By contrast, in Britain, matched graduates have continually improved their relative earnings position compared to underemployed graduates since the mid-1990s (Green and Zhu 2010) and this trend has continued well into the twenty-first century (Green and Henseke 2016a).

\section{Conclusion}

This paper has applied a task-based methodology to derive a classifier for graduate jobs in Germany and applied it to labour force data from 1999, 2006 and 2012. The classifier generates a plausible picture of graduate jobs and explains a range of graduate labour market outcomes better than hitherto existing methods. While it is applied here to investigate trends in the German graduate labour market since the turn of the century, it can be used in a wide range of circumstances where a better understanding of graduate labour market destination is desired. Along with our earlier work, it can serve as a blueprint for similar classifiers. The application of the classifier to labour market data suggests:

- Graduate skills are required beyond the narrow range of professions. Work tasks associated with cognitive skills use are key determinants of higher education requirements on the job.

- The proportion of graduates in the age bracket 25-34 has risen among men from 14.7 to $18.9 \%$ and from 13.3 to $22.5 \%$ among women between 1999 and 2012. Young women have become the group with greatest level of higher education in the labour market.

- The growing supply of graduate labour in the age bracket 25-34 was surpassed by the expansion of employment in graduate jobs. The employment share of graduate jobs shifted by 17 percentage points to almost 30\% among young women and by 11 percentage points to $28 \%$ among young men.

- Among young female graduates, underemployment fell to 22\% between 1999 and 2012; roughly comparable to the level among males at the same ages. Prime aged female graduates, however, experience above average rates of underemployment.

- A sharp rise of the pay premium among men contrasts with stagnating wage differentials among women.

- The pay penalty associated with underemployment has not changed statistically significantly.

Taken together, the evidence points towards a rising excess demand for graduates since 1999. Despite the growing share of university graduates, young graduates in 2012 enjoyed a stable or even growing pay premium at a constant/declining underemployment rate. However, in spite of improving employment figures in Germany after 2005, the employment share of graduate jobs has hardly changed since then.

Neither the derived indicator nor the analysis are free from limitations. Although the approach classifies occupations at a low level of aggregation, skill levels may differ within occupations. By construction, this will be more an issue with KldB-92 than KldB-10 and can account for the lower explanatory power of KldB-92 based classifiers. Furthermore, the classification procedure may not be able to remove all reporting errors if common 
unobservable factors influence task items as well as reported education requirements. Most task items are reported on frequency scales which should minimise subjectivity. Moreover, like other measures of educational mismatch; the approach here does not distinguish between genuine and apparent mismatch. The latter would arise if graduates do not possess the necessary skills to perform graduate roles competently. Though skills heterogeneity explains some underemployment, it is difficult to account for the non-negligible proportion of mismatched graduates solely by differences in skills (Green and Henseke 2016a). The analysis of graduate labour market trends takes a demand-side angle. It is, however, conceivable that a growing supply of graduates encourages employers to open vacancies that draw on graduate skills. While such supply-side effects cannot be ruled out a priori, the figures presented here suggest that demand growth overall outpaced the growth of universityeducated labour. Future trends are less certain as indicated by the sluggish expansion of graduate jobs after 2006. On one hand, the supply of graduates in the labour force is likely to expand further and to become increasingly heterogeneous. On the other, maturation of ICT technology, automation of increasingly complex task bundles, and the global expansion of graduate labour are risk factors that may dampen the future demand for high-level skills.

Acknowledgements This paper uses data from the National Educational Panel Study (NEPS): Starting Cohort Adults, https://dx.doi.org/10.5157/NEPS:SC6:6.0.1. From 2008 to 2013, NEPS data was collected as part of the Framework Program for the Promotion of Empirical Educational Research funded by the German Federal Ministry of Education and Research (BMBF). As of 2014, NEPS is carried out by the Leibniz Institute for Educational Trajectories (LIfBi) at the University of Bamberg in cooperation with a nationwide network.

Funding Funding was provided by Economic and Social Research Council (Grant No. ES/M010082/1).

Open Access This article is distributed under the terms of the Creative Commons Attribution 4.0 International License (http://creativecommons.org/licenses/by/4.0/), which permits unrestricted use, distribution, and reproduction in any medium, provided you give appropriate credit to the original author(s) and the source, provide a link to the Creative Commons license, and indicate if changes were made.

\section{Appendix}

\section{Classification, Validations Results and Further Findings}

In addition to further validation results, this data appendix contains the applied recoding rules for low frequency occupation groups and lists the derived classifiers $\mathrm{KldB}(\mathrm{HE}) 92$ and KldB(HE)10 (see Tables 9, 10, 11, 12, 13).

\section{Data Appendix}

This appendix provides further information about the deployed datasets.

The BiBB/IAB and now the BiBB/BAuA Employment Surveys are large cross-sectional samples of workers. They collect detailed individual-level information on qualification and career histories and job content including work task, work environment, stressors and the organisation from 20,000 up to over 30,000 respondents. The target population are workers aged 15 and older who work at least $10 \mathrm{~h}$ per week. This includes people on paid work placement programmes, helping family members and those who are temporarily not 
in work but with an employment contract. Excluded are apprentices in the dual system, those in compulsory military service and people in voluntary work whether paid or paid or unpaid. Though the overall purpose of the series remained the same since its inception in 1979 , the survey waves have inconsistencies throughout particularly before $2005 / 06$. The data collection mode has changed from face-to-face to telephone with the wave 2005/06 and the questionnaire has seen revisions as well (Rohrbach-Schmidt and Tiemann 2013). Nonetheless, the large number of observation in conjunction with detailed job-level information, make the surveys well suited to derive occupation-specific competence profiles (Rohrbach-Schmidt and Hall 2013). The surveys have, for example, been used in longitudinal research on job tasks and labour market outcomes (e.g., Spitz-Oener 2006, 2008) and to derive classifications of knowledge-intensive occupations (Tiemann 2010). To derive the classifier, I draw on 40,036 observations with complete information in waves 2006 and 2012. The trend analysis is restricted to the workforce aged $25-55$ and uses additional data collected in 1998/99. Numbers of observation change with the specific application.

The National Education Panel Study (NEPS) is a large-scale multi-cohort survey programme to track education decision, learning, attainment and skills development over the life-course. The programme started with around 60,000 participants from early childhood to adulthood (Blossfeld et al. 2011). Unlike many other cohort-studies, NEPS includes longitudinal assessments of skills and competences across multiple domains in conjunction with information on education processes, learning environments, the wider individual socio-economic circumstances and the wider returns to education and skills in adult life. This paper deploys data from the adult start cohort (SC 6) which is a representative sample

Table 9 Stata recoding rules for low-frequency occupations

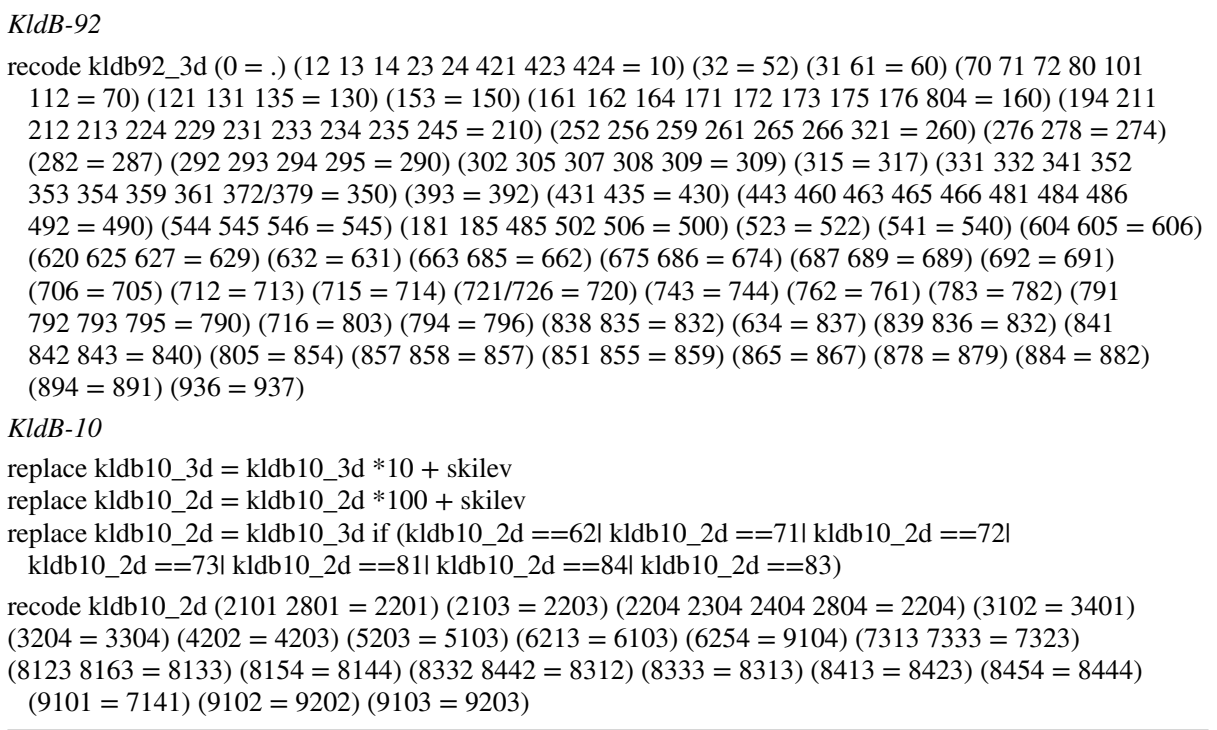




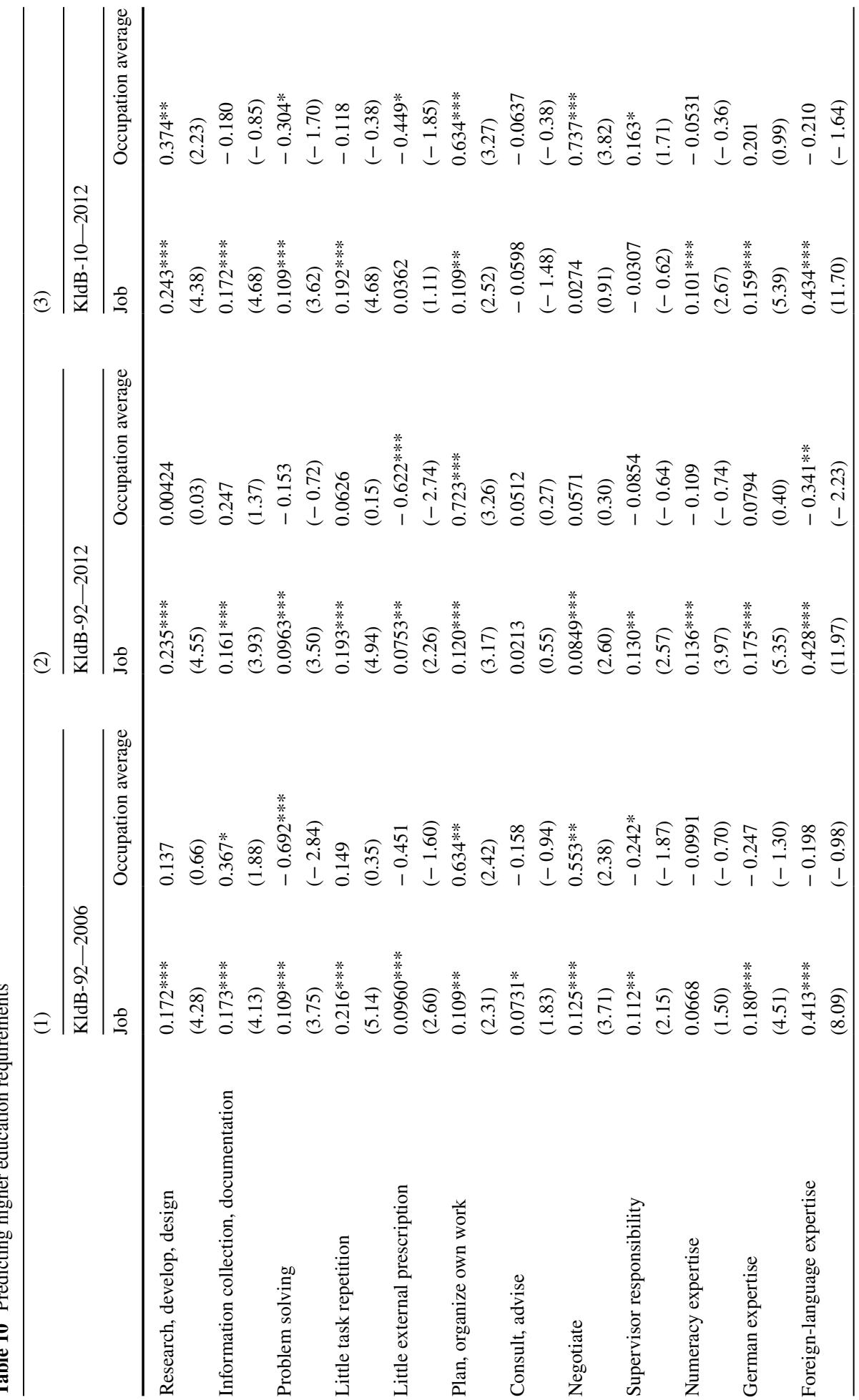




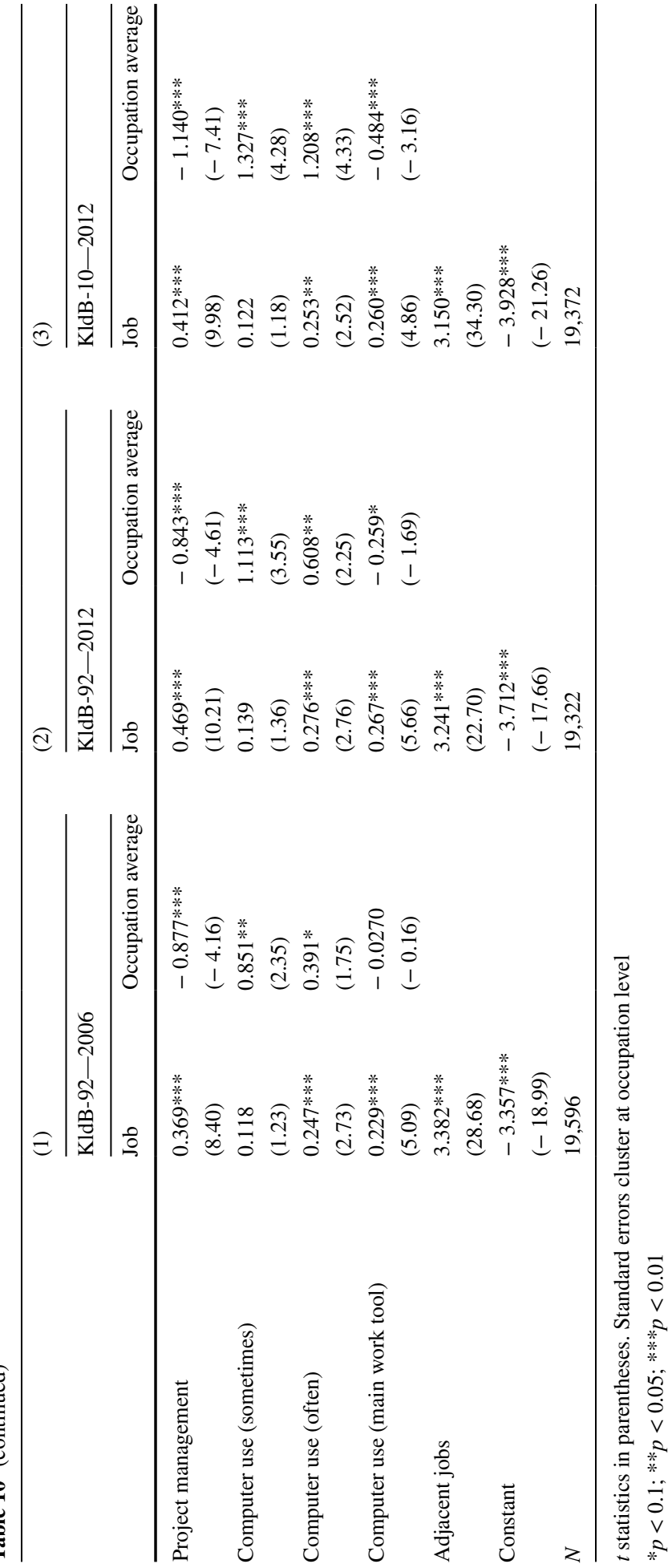


Table 11 Graduate occupations and occupations close to the classification threshold, KldB(HE)92

\begin{tabular}{|c|c|c|c|c|}
\hline 3-Digit & Occupational title (in German) & 2006 & 2012 & Constant \\
\hline 052 & Agraringenieur, Techniker in Gartenbau & 1 & 1 & 1 \\
\hline 060 & Verwalter Land-, Forstwirtschaft & 1 & 1 & 1 \\
\hline 600 & Ingenieure ohne nähere Fachrichtungsangaben & 1 & 1 & 1 \\
\hline 601 & Ingenieure des Maschinen-, Apparate- und & 1 & 1 & 1 \\
\hline 602 & Elektroingenieure & 1 & 1 & 1 \\
\hline 603 & Bauingenieure & 1 & 1 & 1 \\
\hline 606 & Übrige Fertigungsingenieure & 1 & 1 & 1 \\
\hline 607 & Wirtschafts-, REFA-Ingenieure & 1 & 1 & 1 \\
\hline 608 & Sonstige Ingenieure & 1 & 1 & 1 \\
\hline 609 & Architekten, Raumplaner, a.n.g. & 1 & 1 & 1 \\
\hline 611 & Chemiker, Chemie-, Verfahrensingenieure & 1 & 1 & 1 \\
\hline 612 & Physiker, Physikingenieure, Mathematike & 1 & 1 & 1 \\
\hline 623 & Bautechniker & 0 & 1 & 0 \\
\hline 626 & Chemo-, Physikotechniker & 0 & 0 & 0 \\
\hline 628 & Techniker für Betriebswis. und Arbeitss & 0 & 0 & 0 \\
\hline 652 & Ausbilder (f. gew.-techn. Ausbildungsberufe) & 0 & 0 & 0 \\
\hline 703 & Werbefachleute & 1 & 1 & 1 \\
\hline 750 & Unternehmer, Geschäftsführer, a.n.g. & 1 & 1 & 1 \\
\hline 751 & Geschäftsbereichsleiter, Direktionsassitent & 1 & 1 & 1 \\
\hline 753 & Wirtschaftsprüfer, Steuerberater u.v.B. & 1 & 1 & 1 \\
\hline 755 & Marketing-, Absatzfachleute & 1 & 1 & 1 \\
\hline 756 & Organisatoren, Controller & 1 & 1 & 1 \\
\hline 757 & Unternehmensberater & 1 & 1 & 1 \\
\hline 761 & Abgeordnete, Minister, Wahlbeamte & 1 & 1 & 1 \\
\hline 764 & Verwaltungsfachleute (höherer Dienst), & 1 & 1 & 1 \\
\hline 765 & Verwaltungsfachleute (gehobener Dienst) & 1 & 1 & 1 \\
\hline 771 & Finanz-, Rechnungswesenfachleute, Kalkulatoren & 1 & 0 & 1 \\
\hline 774 & Datenverarbeitungsfachleute, Informatik & 1 & 1 & 1 \\
\hline 775 & Softwareentwickler & 1 & 1 & 1 \\
\hline 776 & DV-Organisatoren und verwandte Berufe & 1 & 1 & 1 \\
\hline 777 & DV-Beratungs- und Vertriebsfachleute & 1 & 1 & 1 \\
\hline 778 & Rechenzentrums- und DV-Benutzerservice & 0 & 1 & 1 \\
\hline 779 & Sonstige Datenverarbeitungsfachleute, Informatiker & 1 & 1 & 1 \\
\hline 801 & Soldaten, Grenzschutz-, Polizeibedienst & 1 & 1 & 1 \\
\hline 811 & Richter, Staats-, Amtsanwälte & 1 & 1 & 1 \\
\hline 812 & Rechtspfleger (gehobener Justizdienst) & 1 & 1 & 1 \\
\hline 813 & Rechtsvertreter Rechtsberater & 1 & 1 & 1 \\
\hline 821 & Publizisten & 1 & 1 & 1 \\
\hline 822 & Dolmetscher, Übersetzer & 1 & 1 & 1 \\
\hline 823 & Bibliothekare, Archivare, Museumsfachle & 1 & 1 & 1 \\
\hline 831 & Musiker & 1 & 1 & 1 \\
\hline 833 & Bildende Künstler (freie Kunst) & 1 & 1 & 1 \\
\hline 834 & Bildende Künstler (angewandte Kunst) & 1 & 1 & 1 \\
\hline 840 & Ärzte & 1 & 1 & 1 \\
\hline
\end{tabular}


Table 11 (continued)

\begin{tabular}{lllll}
\hline 3 -Digit & Occupational title (in German) & 2006 & 2012 & Constant \\
\hline 844 & Apotheker & 1 & 1 & 1 \\
861 & Sozialarbeiter, Sozialpädagogen & 1 & 1 & 1 \\
862 & Heilpädagogen & 1 & 1 & 1 \\
868 & Arbeits-, Berufsberater & 1 & 1 & 1 \\
870 & Lehrer ohne nähere Angabe & 1 & 1 & 1 \\
871 & Hochschullehrer und verwandte Berufe & 1 & 1 & 1 \\
872 & Gymnasiallehrer & 1 & 1 & 1 \\
873 & Grund-, Haupt-, Real-, Sonderschullehre & 1 & 1 & 1 \\
874 & Lehrer an berufsbildenden Schulen & 1 & 1 & 1 \\
875 & Lehrer für musische Fächer, a.n.g. & 1 & 1 & 1 \\
876 & Sportlehrer & 1 & 1 & 1 \\
879 & Sonstige Lehrer & 1 & 1 & 1 \\
880 & Wissenschaftler o.n.A. & 1 & 1 & 1 \\
881 & Wirtschaftswissenschaftler, a.n.g. & 1 & 1 & 1 \\
882 & Geistes-, Sozialwissenschaftler & 1 & 1 & 1 \\
883 & Naturwissenschaftler, a.n.g. & 1 & 1 & 1 \\
885 & Erziehungswissenschaftler, a.n.g. & 1 & 1 & 1 \\
886 & Psychologen & 1 & 1 & 1 \\
887 & Statistiker, Marktforscher und verwandt & 1 & 1 & 1 \\
891 & Geistliche, Seelsorger & 1 & 1 & 1
\end{tabular}




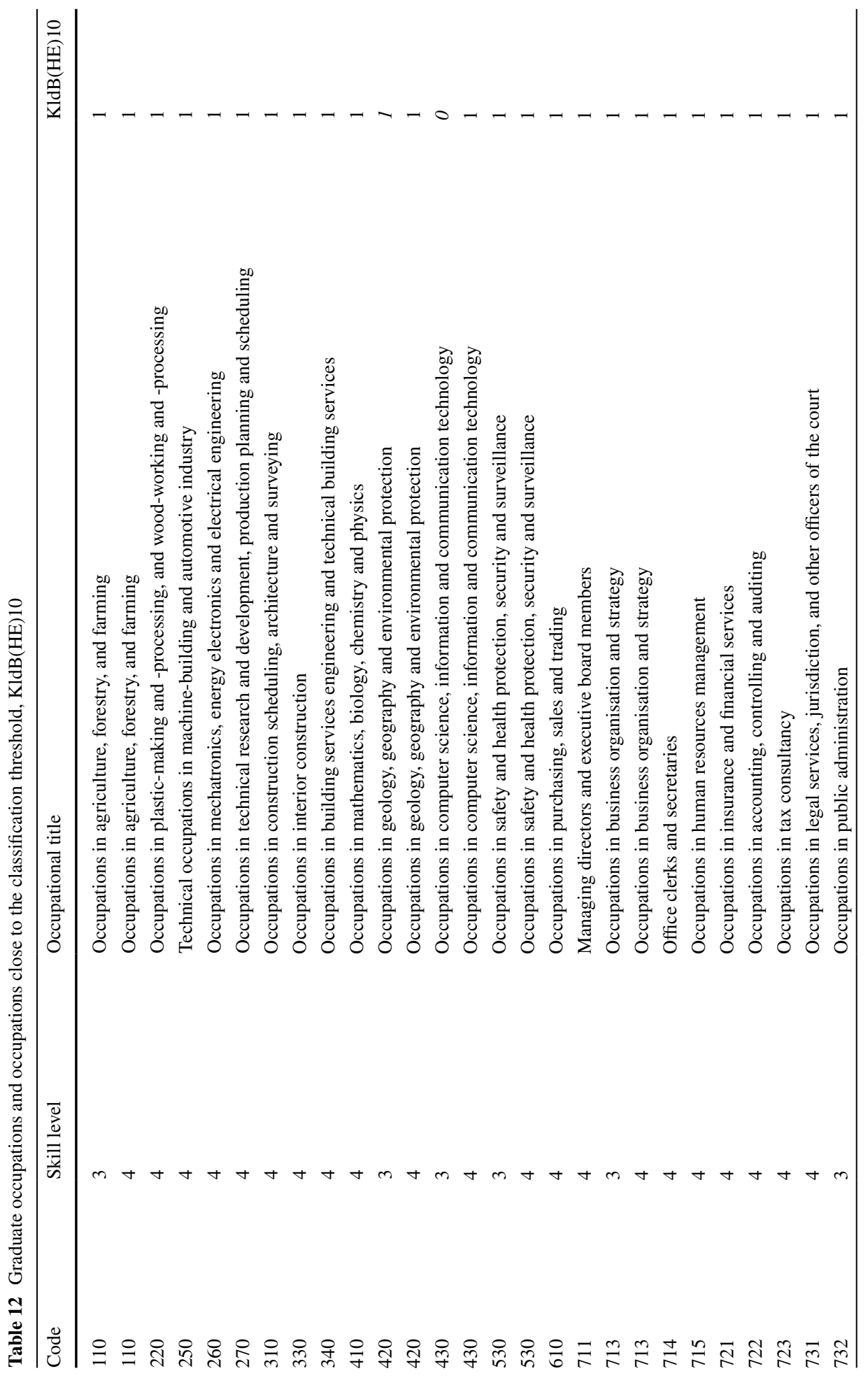




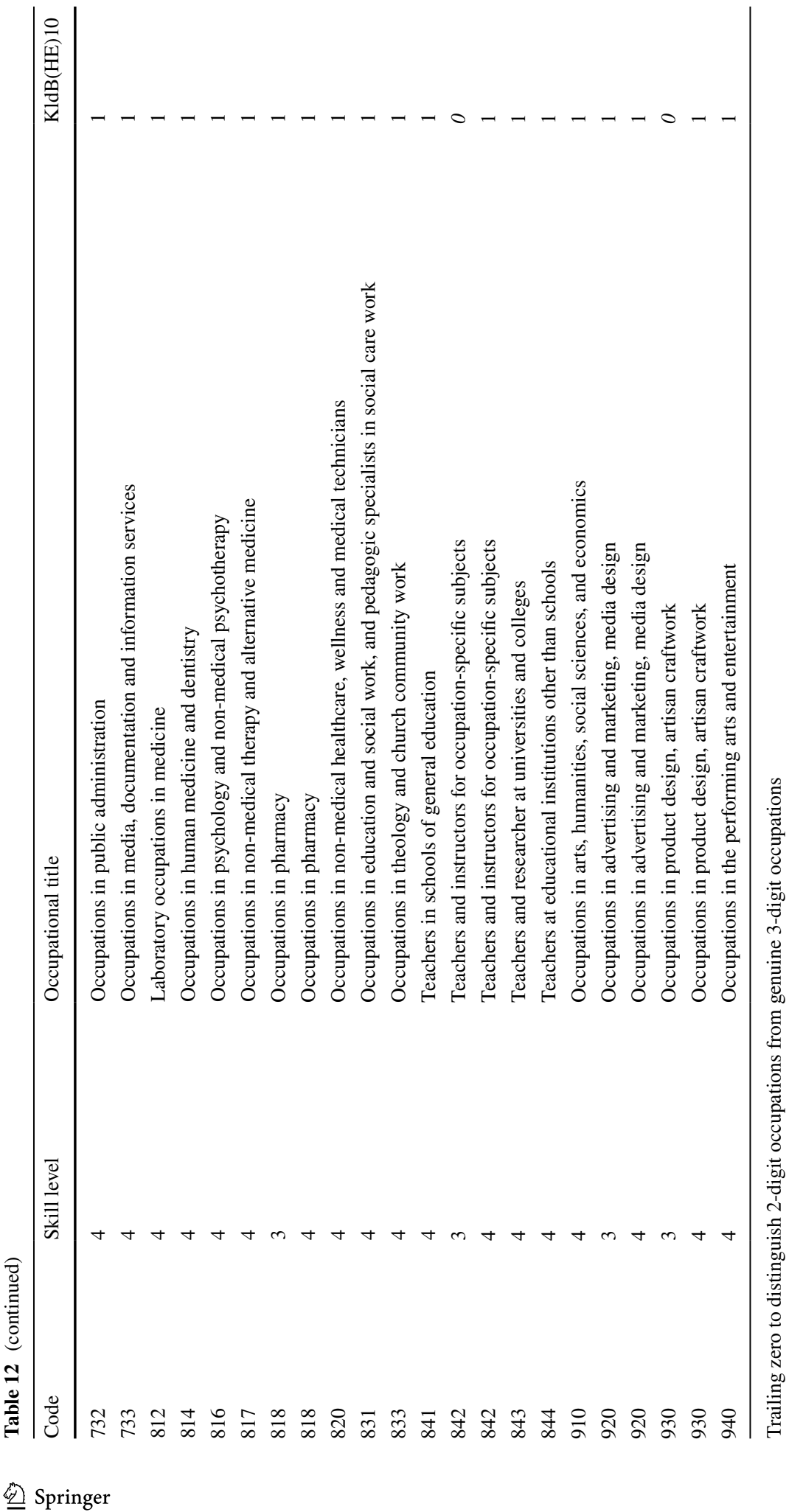


Table 13 Validation of KldB(HE)92 and KldB(HE)10 using NEPS. Source: NEPS SC6 7.0.0. Waves three to six. Employed graduates aged between 25 and 64 years old at the start of their current job

\begin{tabular}{lllll}
\hline & $(1)$ & $(2)$ & $(3)$ & $(4)$ \\
& KldB(HE)10 & KldB(SL4)10 & KldB(HE)92 & KldB(RM)92 \\
\hline $\begin{array}{l}\text { Hourly earnings }(\text { OLS }) \\
\text { Graduate occupation }\end{array}$ & $0.329 * * *$ & $0.290^{* * *}$ & & \\
& $(0.024)$ & $(0.022)$ & $(0.343 * * *$ & $0.232 * * *$ \\
$\mathrm{~N}$ & 2423 & 2423 & 2423 & $(0.021)$ \\
AIC & 2833.9 & 2857.4 & 2845.8 & 2423 \\
$\Delta_{i}$ & -23.50 & 0.00 & -11.60 & 2928.7 \\
Participation in non-formal training (Probit, AME) & & 71.30 \\
Graduate occupation & $0.101 * * *$ & $0.0797 * * *$ & $0.100 * * *$ & $0.0865 * * *$ \\
& $(0.018)$ & $(0.017)$ & $(0.019)$ & $(0.017)$ \\
$\mathrm{N}$ & 3533 & 3533 & 3533 & 3533 \\
AIC & 4466.8 & 4475.5 & 4470.3 & 4471.4 \\
$\Delta_{i}$ & -8.7 & 0 & -5.2 & -4.1 \\
\hline
\end{tabular}

Outcomes are (I) log gross hourly earnings and (II) participation in non-formal trainings. Controls: sex, 5-year age groups, region of work, migration status. AIC Akaike Information Criteria, $\Delta_{i}=A I C_{i}-A I C_{K l d B(S L 4) 10}$. Cluster robust standard errors in parentheses

$* p<0.05 ; * * p<0.01 ; * * * p<0.001$

of 23-64 year-olds irrespective of labour market status. Data collection commenced in 2009 with yearly interviews since. Job and employment data is coded in spell form. To validate the classifier, I combine information about the employment spell with individual characteristics. The sample is restricted to active employment spells in NEPS wave three and onward (2011-2015) in the university-educated workforce aged 25-64 years at the start of the active employment episode. Occupations are coded according to the German Classification of Occupation 2010 and 1988. To load in the derived classifiers, I recode KldB-10 occupations and deploy a cross-walk from KldB-88 to KldB-92. In total, there are 2423 separate employment episode with complete information for the wage assessment and 3533 spells to examine differences in training.

The European Union Labour Force Survey (EU-LFS) is the largest European dataset of adult individuals in private households. It provides both quarterly and annual data on labour market indicators and individual characteristics across the EU member states and associated countries. Data is collected separately by each country according to standards set out by the European Commission (Eurostat 2016). In Germany, EU-LFS is carried out as part of the annual 'micro-census'; a $1 \%$ random probability sample of the residential population. Participation in the micro-census is compulsory. The full micro-census sample became available for EU-LFS data collection in 2012. Educational attainment is coded to ISCED-97 (International Standard Classification of Education) where ISCED groups 5A and 6 comprise university-level qualifications. For this paper, I use annual data files from 1999 to 2012 and restrict the sample to economically active 25 to 54-year-olds. 


\section{References}

Acemoglu, D., \& Autor, D. (2011). Skills, tasks and technologies: Implications for employment and earnings. In D. Card, \& O. Ashenfelter (Eds.), Handbook of labor economics (Vol. 4, Part B, pp. 10431171). Amsterdam: Elsevier.

Akerman, A., Gaarder, I., \& Mogstad, M. (2015). The skill complementarity of broadband internet. The Quarterly Journal of Economics, 130(4), 1781-1824.

Albrecht, J., \& Vroman, S. (2002). A matching model with endogenous skill requirements. International Economic Review, 43(1), 283-305.

Alesi, B., \& Teichler, U. (2013). Akademisierung von Bildung und Beruf-ein kontroverser Diskurs in Deutschland. In E. Severing, \& U. Teichler (Eds.), Akademisierung der Berufswelt? (pp. 19-42). Bonn: Bundesinstitut für Berufsbildung.

Allen, J., \& Van der Velden, R. (Eds.). (2011). The flexible professional in the knowledge society: New challenges for higher education. Berlin: Springer.

Autor, D. H., Katz, L. F., \& Kearney, M. S. (2008). Trends in US wage inequality: Revising the revisionists. The Review of economics and statistics, 90(2), 300-323.

Autor, D. H., Levy, F., \& Murnane, R. J. (2003). The skill content of recent technological change: An empirical exploration. The Quarterly Journal of Economics, 118(4), 1279-1333.

Autorengruppe Bildungsberichterstattung. (2014). Bildung in Deutschland 2014: Ein indikatorengestützter Bericht mit einer Analyse zur Bildung von Menschen mit Behinderungen.

Autorengruppe Bildungsberichterstattung. (2016). Bildung in Deutschland 2016: Ein indikatorengestützter Bericht mit einer Analyse zu Bildung und Migration.

Baethge, M., \& Wolter, A. (2015). The German skill formation model in transition: From dual system of VET to higher education? Journal for Labour Market Research, 48(2), 97-112.

Blinder, A. S., \& Krueger, A. B. (2013). Alternative measures of offshorability: A survey approach. Journal of Labor Economics, 31(S1), S97-S128.

Blossfeld, H. P., von Maurice, J., \& Schneider, T. (2011). 1 The National Educational Panel Study: Need, main features, and research potential. Zeitschrift für Erziehungswissenschaft, 14(2), 5-17.

Blundell, R., Green, D., \& Jin, W. (2016). The UK wage premium puzzle: How did a large increase in university graduates leave the education premium unchanged? (No. W16/01). Institute for Fiscal Studies.

Boccuzzo, G., \& Gianecchini, M. (2015). Measuring young graduates' job quality through a composite indicator. Social Indicators Research, 122(2), 453-478.

Boll, C., Leppin, J. S., \& Schömann, K. (2016). Who is overeducated and why? Probit and dynamic mixed multinomial logit analyses of vertical mismatch in East and West Germany. Education Economics, 24(6), 639-662.

Burnham, K. P., \& Anderson, D. R. (2004). Multimodel inference: Understanding AIC and BIC in model selection. Sociological methods \& research, 33(2), 261-304.

Cattani, L., Purcell, K., \& Elias, P. (2014). SOC (HE)-Italy: A classification for graduate occupations. Quaderni-Working Paper DSE, No. 963.

Christoph, B., Leber, U., \& Stüber, H. (2017). Einkommen von Bachelor- und anderen Hochschulabsolventen: Höhere Abschlüsse zahlen sich mit dem Alter zunehmend aus. IAB-Kurzbericht, 13/2017.

Dengler, K., Matthes, B., \& Paulus, W. (2014). Occupational tasks in the German Labour Market-An alternative measurement on the basis of an expert database. FDZ method reports. 12/2014.

Destatis. (2016). Nichtmonetäre hochschulstatistische Kennzahlen. Fachserie 11 Reihe 4.3.1-1980-2015. https://www.destatis.de/DE/Publikationen/Thematisch/BildungForschungKultur/Hochschulen/Kennz ahlenNichtmonetaer.html. Accessed 13 Feb 2017.

Dolado, J. J., Jansen, M., \& Jimeno, J. F. (2009). On-the-Job search in a matching model with heterogeneous jobs and workers. The Economic Journal, 119(534), 200-228.

Dollase, R. (2016). Alle wollen "Abi" und "Uni" : Über tabuisierte Ursachen von Bildungshysterie. In P. Bodensteiner, \& J. Kraus (Eds.), Akademikerschwemme versus Fachkräftemangel (pp. 21-54). München: Hanns-Seidel-Stiftung.

Drexel, I. (2010). Gesellschaftliche und politische Folgen von Akademisierung. In: IG METALL (Hrsg.), Dokumentation des Workshops: Akademisierung von Betrieben - Facharbeiter/innen ein Auslaufmodell? (pp. 47-54).

Dustmann, C., Fitzenberger, B., Schönberg, U., \& Spitz-Oener, A. (2014). From sick man of Europe to economic superstar: Germany's resurgent economy. The Journal of Economic Perspectives, 28(1), $167-188$.

Dustmann, C., \& Glitz, A. (2015). How do industries and firms respond to changes in local labor supply? Journal of Labor Economics, 33(3), 711-750. 
Dustmann, C., Ludsteck, J., \& Schönberg, U. (2009). Revisiting the German wage structure. The Quarterly Journal of Economics, 124(2), 843-881.

Elias, P., \& Purcell, K. (2004). Is mass higher education working? Evidence from the labour market experiences of recent graduates. National Institute Economic Review, 190(1), 60-74.

Elias, P., \& Purcell, K. (2013). Classifying graduate occupations for the knowledge society. Institute for Employment Research. University of Warwick. Futuretrack working paper, 5.

Eurostat. (2016). EU Labour Force Survey Database User Guide. http://ec.europa.eu/eurostat/docum ents/1978984/6037342/EULFS-Database-UserGuide.pdf. Accessed June 2017.

Everitt, B. S., \& Dunn, G. (2001). Applied multivariate data analysis (Vol. 2). London: Arnold.

Foster-McGregor, N., Stehrer, R., \& de Vries, G. J. (2013). Offshoring and the skill structure of labour demand. Review of World Economics, 149(4), 631-662.

Goldschmidt, D., \& Schmieder, J. F. (2017). The rise of domestic outsourcing and the evolution of the German wage structure. The Quarterly Journal of Economics, 132(3), 1165-1217.

Goos, M., Manning, A., \& Salomons, A. (2014). Explaining job polarization: Routine-biased technological change and offshoring. The American Economic Review, 104(8), 2509-2526.

Gottschalk, P., \& Hansen, M. (2003). Is the proportion of college workers in noncollege jobs increasing? Journal of Labor Economics, 21(2), 449-471.

Green, F. (2012). Employee involvement, technology and evolution in job skills: A task-based analysis. ILR Review, 65(1), 36-67.

Green, F., \& Henseke, G. (2016a). The changing graduate labour market: Analysis using a new indicator of graduate jobs. IZA Journal of Labor Policy, 5(1), 14.

Green, F., \& Henseke, G. (2016b). Should governments of OECD countries worry about graduate underemployment? Oxford Review of Economic Policy, 32(4), 514-537.

Green, F., \& Zhu, Y. (2010). Overqualification, job dissatisfaction, and increasing dispersion in the returns to graduate education. Oxford Economic Papers, 62(4), 740-763.

Hanushek, E. A., Schwerdt, G., Woessmann, L., \& Zhang, L. (2017). General education, vocational education, and labor-market outcomes over the lifecycle. Journal of Human Resources, 52(1), 48-87.

Haupt, A. (2016). Do occupational licenses increase wages and wage inequality? Zeitschrift fur Soziologie, $45(1), 39-56$.

Henseke, G., \& Green, F. (2017). Cross-national deployment of "Graduate Jobs": Analysis using a new indicator based on high skills use. In S. W. Polachek, K. Pouliakas, G. Russo, et al. (Eds.), Skill mismatch in labor markets (Vol. 45, pp. 41-79). Research in Labor Economics Bingley: Emerald Publishing Limited.

Hirsch-Kreinsen, H. (2013). Wie viel akademische Bildung brauchen wir zukünftig? Ein Beitrag zur Akademisierungssdebate. Konrad-Adenauer-Stiftung Analysen \& Argumente, No. 136.

Jacob, M., \& Solga, H. (2015). Germany's vocational education and training system in transformation: Changes in the participation of low-and high-achieving youth over time. European Sociological Review, 31(2), 161-171.

Katz, L. F., \& Murphy, K. M. (1992). Changes in relative wages, 1963-1987: Supply and demand factors. The Quarterly Journal of Economics, 107(1), 35-78.

Kiker, B. F., Santos, M. C., \& De Oliveira, M. M. (1997). Overeducation and undereducation: Evidence for Portugal. Economics of Education Review, 16(2), 111-125.

Klein, M. (2015). The increasing unemployment gap between the low and high educated in West Germany. Structural or cyclical crowding-out? Social Science Research, 50, 110-125.

Lamo, A., Messina, J., \& Wasmer, E. (2011). Are specific skills an obstacle to labor market adjustment? Labour Economics, 18(2), 240-256.

Mateos-Romero, L., \& del Mar Salinas-Jiménez, M. (2017). Skills heterogeneity among graduate workers: Real and apparent overeducation in the Spanish labor market. Social Indicators Research, 132(3), 1247-1264.

McMahon, W. W. (2009). Higher learning, greater good: The private and social benefits of higher education. Baltimore, MD: JHU Press.

Michaels, G., Natraj, A., \& Van Reenen, J. (2014). Has ICT polarized skill demand? Evidence from eleven countries over twenty-five years. Review of Economics and Statistics, 96(1), 60-77.

Nida-Rümelin, J. (2014). Der Akademisierungswahn: zur Krise beruflicher und akademischer Bildung. Hamburg: Edition Körber-Stiftung.

O'Leary, N., \& Sloane, P. (2016). Too many graduates? An application of the Gottschalk-Hansen model to young British graduates between 2001-2010. Oxford Economic Papers, 68(4), 945-967.

OECD. (2008). Education at a glance 2008: OECD indicators. Paris: OECD Publishing.

Paulus, W., \& Matthes, B. (2013). Klassifikation der Berufe: Struktur, Codierung und Umsteigeschlïssel. FDZ-Methodenreport, 08/2013. 
Powell, J. J., \& Solga, H. (2011). Why are higher education participation rates in Germany so low? Institutional barriers to higher education expansion. Journal of Education and Work, 24(1-2), 49-68.

Protsch, P., \& Solga, H. (2016). The social stratification of the German VET system. Journal of Education and Work, 29(6), 637-661.

Reinhold, M., \& Thomsen, S. (2017). The changing situation of labor market entrants in Germany. Journal for Labour Market Research, 50(1), 161-174.

Rohrbach-Schmidt, D., \& Hall, A. (2013). BIBB/BAuA-Erwerbstätigenbefragung 2012. BIBB-FDZ Datenund Methodenbericht, Nr. 1/2013.

Rohrbach-Schmidt, D., \& Tiemann, M. (2013). Changes in workplace tasks in Germany-Evaluating skill and task measures. Journal for Labour Market Research, 46(3), 215-237.

Schütte, F. (2013). Konkurrenz von akademischer und nicht akademischer Bildung-mehr als ein Phänomen? In E. Severing, \& U. Teichler (Eds.), Akademisierung der Berufswelt? (pp. 43-62). Bonn: Bundesinstitut für Berufsbildung.

Spitz-Oener, A. (2006). Technical change, job tasks, and rising educational demands: Looking outside the wage structure. Journal of Labor Economics, 24(2), 235-270.

Spitz-Oener, A. (2008). The returns to pencil use revisited. ILR Review, 61(4), 502-517.

Summerfield, F., \& Theodossiou, I. (2017). The effects of macroeconomic conditions at graduation on overeducation. Economic Inquiry, 55(3), 1370-1387.

Teichler, U. (2009). Higher education and the world of work: Conceptual frameworks, comparative perspectives, empirical findings (Vol. 16)., Global perspectives on higher education Rotterdam: Sense Publishers.

Teijeiro, M., Rungo, P., \& Freire, M. J. (2013). Graduate competencies and employability: The impact of matching firms' needs and personal attainments. Economics of Education Review, 34, 286-295.

Tiemann, M. (2010). Wissensintensive Berufe. Wissenschaftliche Diskussionspapiere des Bundesinstitut für Berufsbildung, 114, 1-70.

Tiemann, M., Schade, H. J., Helmrich, R., Hall, A., Braun, U. \& Bott, P. (2008). Berufsfeld-Definitionen des BIBB. Bundesinstitut für Berufsbildung. https://metadaten.bibb.de/download/1615.

Valletta, R. G. (2017). Recent flattening in the higher education wage premium: polarization, skill downgrading, or both? In C. Hulten, \& V Ramsey (Eds.), Education, Skills, and Future U.S. GDP Growth. NBER Book Series Studies in Income and Wealth. Chicago: University of Chicago Press, forthcoming.

Van Reenen, J. (2011). Wage inequality, technology and trade: 21st century evidence. Labour economics, 18(6), 730-741.

Verdugo, R. R., \& Verdugo, N. T. (1989). The impact of surplus schooling on earnings: Some additional findings. J Hum Resour, 24, 629-643.

Verhaest, D., \& Omey, E. (2006). The impact of overeducation and its measurement. Social Indicators Research, 77(3), 419-448.

Verhaest, D., \& Omey, E. (2012). Overeducation, undereducation and earnings: Further evidence on the importance of ability and measurement error bias. Journal of Labor Research, 33(1), 76-90.

Walker, I., \& Zhu, Y. (2008). The college wage premium and the expansion of higher education in the UK. The Scandinavian Journal of Economics, 110(4), 695-709.

Weber, S. (2014). Human capital depreciation and education level. International Journal of Manpower, 35(5), 613-642.

Wolter, A., \& Kerst, C. (2015). The 'academization' of the German qualification system: Recent developments in the relationships between vocational training and higher education in Germany. Research in Comparative and International Education, 10(4), 510-524.

Wolter, S. C., \& Ryan, P. (2011). Apprenticeship. In E. A. Hanushek, S. J. Machin, \& L. Woessmann (Eds.), Handbook of the economics of education (Vol. 3, pp. 521-576). Amsterdam: Elsevier. 